ISSN: 1857-9833

UDC: 55

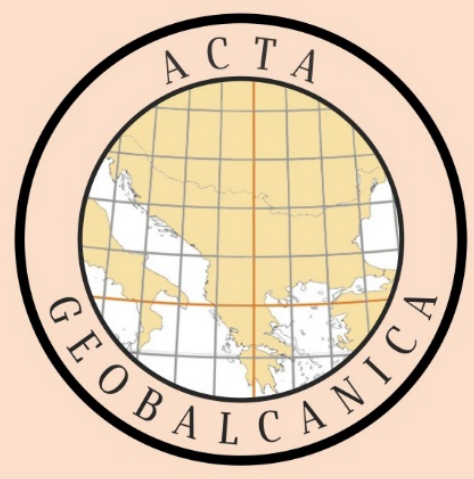

E

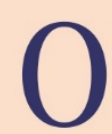

B

A

L

C

A

$\mathrm{N}$

I

C

A

C

$\mathrm{T}$

A

volume 7 | issue 4 | pp. 137-173 | 2021 



\title{
ACTA GEOBALCANICA
}

Online-ISSN: 1857-9833 UDK: 55 DOI: https://doi.org/10.18509/AGB.2015

\author{
Publisher: Geobalcanica Society \\ info@geobalcanica.org \\ Editor-in-chief \\ Ivan Radevski, $\mathrm{PhD}$, Associate Professor, \\ Institute of Geography, Faculty of Natural Sciences and Mathematics in Skopje, \\ Ss. Cyril and Methodius University, Republic of North Macedonia \\ svemir@pmf.ukim.mk
}

\section{Deputy Editor-in-chief}

Svemir Gorin, $\mathrm{PhD}$, Associate Professor,

Institute of Geography, Faculty of Natural Sciences and Mathematics in Skopje,

Ss. Cyril and Methodius University, Republic of North Macedonia

ivan.radevski@pmf.ukim.mk

\section{INTERNATIONAL EDITORIAL BOARD:}

Arild Holt-Jensen, PhD, Professor Emeritus Department of Geography, University of Bergen Norway

Péter Bagoly-Simó, PhD, Professor Geography Department, Humboldt University

Germany

Drago Perko, PhD, Director

Anton Melik Geographical Institute

Slovenian Academy of Sciences and Arts

Slovenia

Daniele La Rosa, PhD, Assistant Researcher

Department of Civil Engineering and Architecture

Italy

Olgica Dimitrovska, PhD, Full professor,

Institute of Geography,

Faculty of Natural Sciences and Mathematics in Skopje,

Ss. Cyril and Methodius University,

Republic of North Macedonia

Georgi Zhelezov, PhD, Associate Professor,

Head of Section Physical Geography National Institute of

Geophysics,

Geodesy and Geography Bulgarian Academy of Sciences,

Bulgaria

Sanja Faivre, PhD, Full Professor,

Department of Geography, Faculty of Science

University of Zagreb

Croatia

Istvan Egresi, $\mathrm{PhD}$, Assistant Professor

Department of Geography, Fatih University

Turkey

Biljana Apostolovska Toshevska, PhD, Full Professor, Institute of Geography,

Faculty of Natural Sciences and Mathematics in Skopje,

Ss. Cyril and Methodius University,

Republic of North Macedonia.

Riccardo Privitera, PhD, Assistant Researcher

Department of Civil Engineering and Architecture

Italy

Alexandru Onaca, $\mathrm{PhD}$, Researcher

Department of Geography

Western University of Temisoara

Romania
Stefan Bouzarovski, PhD, Professor of Geography, Director of the Centre for Urban Resilience and Energy University of Manchester,

United Kingdom

Sanja Klempic Bogadi, PhD, Senior Research Associate Institute for Migration and Ethnic Studies

Croatia

Rok Ciglič, $\mathrm{PhD}$, Research Fellow

Anton Melik Geographical Institute

Slovenian Academy of Sciences and Arts

Slovenia

Milena Taleska, PhD Associate professor,

Institute of Geography,

Faculty of Natural Sciences and Mathematics in Skopje,

Ss. Cyril and Methodius University,

Republic of North Macedonia

Matija Zorn, PhD, Senior Research Fellow

Assistant Director

Anton Melik Geographical Institute

Research Centre of the Slovenian Academy of Sciences and Arts

Slovenia

Natasa Ravbar, PhD, Associate Professor

Karst Research Institute, Research Centre of the Slovenian

Academy of Sciences and Arts

Republic of Slovenia

Ivica Milevski, $\mathrm{PhD}$, Full Professor

Institute of Geography,

Faculty of Natural Sciences and Mathematics in Skopje,

Ss. Cyril and Methodius University,

Republic of North Macedonia

Stephan Glatzel, PhD, Full Professor

Department of Geography and Regional Research

Faculty of Earth Sciences, Geography and Astronomy

University of Vienna

Republic of Austria

Saska Petrova, PhD, Lecturer

School of Environment, Education and Development

The University of Manchester

United Kingdom

\section{Technical editing}

Vladimir Zlatanoski, MSc, Teaching Assistant,

Institute of Geography, Faculty of Natural Sciences and Mathematics in Skopje,

Ss. Cyril and Methodius University, Republic of North Macedonia

zlatanoski@pmf.ukim.mk

Language: English | Papers are available on-line on: www.acta.geobalcanica.info 



\section{CONTENTS:}

TEMPORARY STREET TRANSFORMATION AS AN INTERVENTION FOR MORE PEOPLE FRIENDLY ENVIRONMENTS IN CITIES.

A CONTRIBUTION WITHIN THE FRAME OF TACTICAL URBANISM

Magdalena Senger, Michael Giesch, Wolfgang Fischer

RELIEF AND SEDIMENTS OF NIDA RIVER VALLEY

NEAR PIŃCZÓW GAP-SECTION - FIRST RESULTS

Marcin Frączek, Tomasz Kalicki, Piotr Biesaga, Karolina Walczyńska.

PALEOENVIRONMENTAL STUDY OF OUM ALI REGION

(TÉBESSA, ALGERIA) DURING QUATERNARY, THROUGH

THE STUDY OF FLUVIAL TERRACE OF KHENIGUE WADI

Defaflia Nabil, Djaiz Fouad, Fehdi Chamseddine.

THE GEOCHEMICAL DIVERSITY OF LACUSTRINE SEDIMENTS

OF THE SUCHEDNIÓW WATER RESERVOIR (ŚWIĘTOKRZYSKIE

VOIVODESHIP, POLAND) - PRELIMINARY RESULTS

Tomasz Kalicki, Rafał Kozłowski, Paweł Przepióra, Mirosław Szwed.

EFFICIENCY OF HALOTHERAPY IN IMPROVING

HUMAN PERFORMANCE IN GYMNASIUM STUDENTS)

Mihaela-Orlanda Antonovici (Munteanu), Chim Ion Sandu, Eng Ioan Gabriel Sandu,

Cristina Carmen Stingu (Palici),Simona Dimitriu (Ursache) 



\title{
TEMPORARY STREET TRANSFORMATION AS AN INTERVENTION FOR MORE PEOPLE FRIENDLY ENVIRONMENTS IN CITIES, A CONTRIBUTION WITHIN THE FRAME OF TACTICAL URBANISM
}

\author{
DOI: https://doi.org/10.18509/AGB217-40137s \\ UDC: 711.73-048.25:712.254-022.326 \\ Magdalena Senger, Michael Giesch, Wolfgang Fischer \\ Department of Geography and Regional Science, University of Graz, Austria \\ corresponding author:
}

submitted: 04.01.2021

accepted: 03.03.2021

published: 20.07.2021

\begin{abstract}
The paper in hand reflects on a research project named "Pop-up Piazza". It explores transformative tools for the temporary transformation of public space on streets. The principle is to test temporary measures from smaller actions like parklets to bigger actions such as closing streets for traffic before detailed planning or cost-intensive structural changes are made.

Public street space is largely dominated by motor vehicle use. Our pop-up transformations test other traffic conditions and enable a perception of the car-free space and its potential to make public space more people-friendly. Small, simple and inexpensive interventions should make the application easier for many cities. To implement this, we have developed cargo bike-based prototypes (so called Street Formators) within the project and are testing them in the urban spaces of Vienna and Graz. In addition to the development of prototypes and pilot testing in different frameworks, another focus lies on the impact evaluation of the implementations. Recommendations for policy makers, administrators, planners and developers will be derived from the results of the evaluation.

The case studies Graz and Vienna show that the framework conditions strongly contribute to the success of the measures. The temporary transformation of public street space creates more space for social interaction, fulfills an important function for neighborhoods and thus contributes to the quality of life in cities.
\end{abstract}

Keywords: tactical urbanism, streets for everyone, sustainable urban development, livable city, public space

\section{INTRODUCTION}

In urban areas - influenced not least by population growth and urbanization processes - various challenges are becoming increasingly apparent. Urban planners and developers are faced with problems such as degradation of air quality, noise pollution, rising temperatures and much more. Solutions to these must ensure that the current development results in well-functioning environmentally friendly and sustainable cities. For this, a combination of factors is needed. One of them is the proper administrative structures that influence outcomes in many areas that contribute to a functioning city. These include in particular transportation planning and land use planning. Specifically, ordinances must strike a balance between protecting existing neighborhoods, green space, and new development. In the context of transport, increasing the quality of public transport is particularly important, as are low incentives for car use to address impacts such as air pollution or congestion [1].This impressive call for a mobility turnaround is strongly linked to a reprioritization of urban street space in favour of sustainable modes of transport. Since the rise of the car, people have been increasingly marginalized - in favour of motorized transport. But since the street is more than a space to get around - street space fulfils key functions such as commerce, play, social interaction, leisure, etc. - this development has been increasingly challenged in recent times. Therefore, there are attempts to transform the streets in urban areas away from the use by motorized individual traffic towards active mobility and public spaces. The vision behind this is to create "streets for people" to use as recreational spaces, for playing and as places for social interaction [2] [3] [4].

Austria has comparatively little experience in this area. Exceptions are pedestrian zones such as Mariahilferstraße in Vienna [5] and Sonnenfelsplatz in Graz ("shared space") [6] or in front of a few schools and residential streets where traffic-calming measures are in place. In the 
majority of cases, however, the public traffic space is dominated by motorized individual traffic. To a large extent, this space is "blocked" by parked cars.
A look at the spatial distribution of stationary traffic in Graz makes this more than clear:

Table 1. Spatial distribution of stationary traffic in Graz(source: Austrian Mobility Research 2016, based on data from the City of Graz)

\begin{tabular}{|l|c|}
\hline & Land requirement (in \%) \\
\hline Bicycle parking facilities & 2 \\
\hline Pedestrian areas & 3 \\
\hline Areas for public transport & 3 \\
\hline Car parking space & 92 \\
\hline
\end{tabular}

One way to address this challenge is to view streetscapes as experimental spaces where solutions can be tested - the paradigm is "learning by doing". The experience should contribute to a better understanding of the opportunities [7].

This paper will explore the possibilities of such temporary transformations and the framework

\section{THEORETICAL FRAMEWORK}

Tactical urbanism consists of low budget and smallscale interventions to generate a more livable environment in cities. Synonyms are "pop-up" and "guerilla" urbanism [8]. The goal is to make a big impact at low risk. The interventions should be shown to a broad audience to give them an idea of possible changes. People should get the experience of what could make their city life more colorful, safer and easier. Changes could range from coloring bicycle lanes up to transforming parking space into chillout areas to flee the daily stress occurring in a pulsating city. Biggest impact of tactical urbanism is generated, when residents or communities start to engage in city planning [9] [10] [11].

Tactical Urbanism is not a new phenomenon. For a long time, cities have had to face different challenges. Adaptations to new economic systems were demanded as Lefebvre addresses in his book "Writings on cities". Planning is done by intellectuals and every possible aspect is included [12] [13].

The focus of urban planners is primarily on securing settlement developments, use of land for buildings and the design of traffic areas [14] [15]. However, no one asks how people feel along busy roads. Nobody asks what elderly people would like to have on their daily walk: e.g. a seating accommodation to rest when walking longer distances. Who thinks of the needs of children living on highly frequented roads? Today the planning of the city is mainly based on factors of economic importance. conditions that contribute to success. After a review of the theoretical framework of tactical urbanism and its current state of research, we will focus on the research project Pop-up Piazza. After outlining the contents and goals, we present our interim results of the surveys in the case studies Vienna and Graz (both cities in Austria).

Tactical urbanism is a means for city dwellers to express their needs. This informal approach, which might fall under civil disobedience, all the same achieves its goals. Often, short-term interventions are recognized and adopted by official bodies at a later stage. For example, the project "walk [your city]" showed this. The American city Raleigh first banned the project as illegal. Due to high media attention and high support of the citizens, officials shortly afterwards reinstated the intervention and declared the changes as a pilot project [16].

Tactical urbanism can be found in many cities. In Vienna, a temporary improvement is achieved within the framework of the "Coole Straßen" (in English: "cool streets" - further on this term is used). On a heat map, places are selected which need cooling down during the summer months and thus interventions such as closing automotive traffic, water sprinklers, mobile plants in large pots and installing meeting places [17]. The "Grätzloase" (in English: "neighbourhood oases") can be mentioned here as another action program. The initiative shows how small spaces in the neighbourhood can be used and bring life back to the streets. To achieve this, mostly parklets are employed - a use of car parking spaces as lounges. In addition to this method, which has already been used in Vienna, but mostly for longer periods - e.g. the parklets are set up for a season or longer - we want to test simple and quick pop-up transformations in the course of the project with the help of a new tool [18]. 
THE "POP-UP PIAZZA” PROJECT

Changes of built environment in cities are generally accompanied by long lasting decision making and planning processes. This circumstance makes it more difficult to implement modern urban development concepts that are intended to bring about a transformation in mobility patterns and to make public spaces more people- and childfriendly. The statement of intent might be written down on paper - but very often there is a lack of budget, time and consensus around the kind of measures that should be implemented. Often these obstacles are irremovable.

Temporarily freeing traffic areas from cars and transforming them into public spaces, offers a "lowcost", "low-time" and "high gain" opportunity to reduce the obstacles associated with the transformation of urban structures towards new traffic concepts and paradigms. The principle is to temporarily test a measure before the cost-intensive detailed planning and implementation of construction measures. A wide variety of temporary transformations is to be developed as an efficient, potentially widely used planning and implementation tool for sustainable, permanent solutions.Pop-up Piazza aims to make the temporary transformation of streets and squares

\section{EXPERIENCES WITH THE}

\section{TRANSFORMATION OF STREET}

\section{SPACES IN DIFFERENT CONTEXTS}

A central point of the project are the interventions, i.e. the "testing out" of the StreetFormators in different settings and the evaluation of the impact. The goal is to conduct 20 and 10 interventions in the cities of Vienna and Graz, respectively. Due to the changed situation caused by Covid, there were delays in the implementation and adjustments had to be made. Thus, instead of the prototypes, the so- much easier and faster to implement and to make it easy for Austrian cities to apply. The goal is to create an efficient tool for a widely applied, multifaceted transformation of public spaces that will significantly accelerate the mobility turnaround. The main results of Pop-up Piazza will be [19]:

-Development and testing of cargo bike-based research prototypes, which - as mobile "StreetFormators" - will enable fast pop-up transformations.

-(Further) development and testing of a digital citizens' tool, which is suitable for the broad employment on different topics all over Austria.

-The respective "testing" is about the validation of the functionalities - how the respective solution is proven or not proven in the real laboratory environment.

-State of the art analysis and analysis of the legal and organizational framework conditions

-Evaluation and recommendations for policy, administration, planners and developers

-Efficient dissemination of research results, opensource access for prototypes and the citizens' tool. called StreetFormators, which had not all been built yet, the existing "Raumwandler" (in English: "space-transformers") from the previous project Metamorphosis were used (in Graz). One readybuilt StreetFormator - a cargo bike equipped with games, fun and sports equipment - was already in use in Vienna.
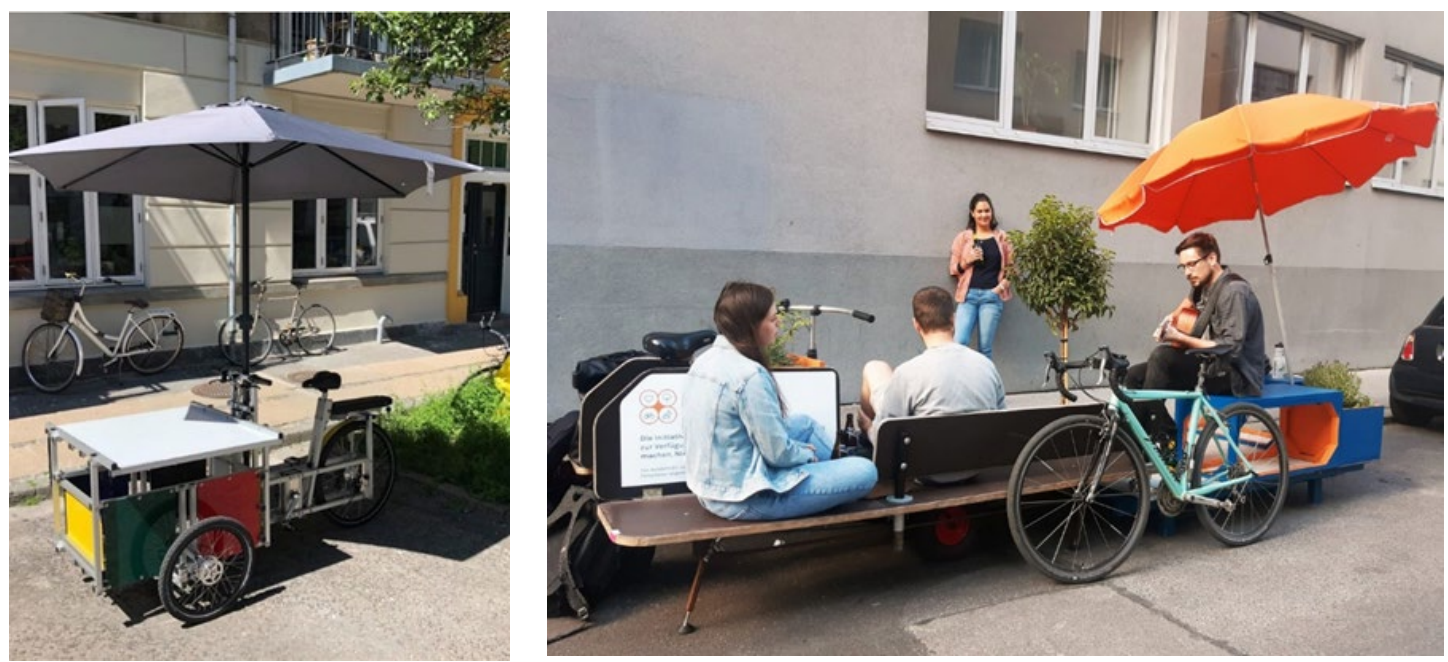

Figure 1: The new StreetFormator called "playing-bike" and the existing space-transformers (Sources: xyz cargo 2020; metamorphosis 2020) 


\section{Magdalena Senger et al.. \\ Temporary street transformation as an...}

In addition to the different transformation tools that were used, they were also applied in different contexts. While the main focus in Graz was a host system, in Vienna the use was carried out in the context of events (see table 2) [20].

Table 2: Difference in the way of interventions in Graz and Vienna

\begin{tabular}{|l|l|l|}
\hline & \multicolumn{1}{|c|}{ Graz } & \multicolumn{1}{c|}{ Vienna } \\
\hline Type of prototypes used & $\begin{array}{l}\text { Space-transformers (which } \\
\text { were developed for the } \\
\text { Metamorphosis project) as a } \\
\text { replacement for StreetFormators } \\
\begin{array}{l}\text { "garden mobile" and } \\
\text { "classic" space-transformers } \\
\text { (see figure 1) }\end{array}\end{array}$ & $\begin{array}{l}\text { StreetFormator } \\
\text { (playing bike) (see figure 1) }\end{array}$ \\
\hline $\begin{array}{l}\text { Context in which the } \\
\text { prototypes were used }\end{array}$ & $\begin{array}{l}\text { Space-transformers: host } \\
\text { system and unsupervised } \\
\text { release; } \\
\text { "garden mobile": in cooperation } \\
\text { with the Social Welfare Office } \\
\text { of the City of Graz and a host } \\
\text { system }\end{array}$ & Event "Cool Streets" \\
\hline Participation principle & $\begin{array}{l}\text { Modified bottom-up } \\
\text { (Cooperation with local } \\
\text { associations, institutions and } \\
\text { companies) }\end{array}$ & $\begin{array}{l}\text { Top-down } \\
\text { (Cool streets: official closure of } \\
\text { the streets) }\end{array}$ \\
\hline
\end{tabular}

The Graz deployments were conducted in a "modified bottom-up" framework. Specifically, this means that the selection of the sites themselves was not a top-down measure on the part of authorities or administrative units. Nor have citizens themselves had any direct influence on the location of the deployed space-transformers yet.
Instead, cooperative partnerships were formed in which the location was jointly fixed. In addition to the project partners, non-profit organizations, local companies and associations were represented in such partnerships [20]. In figure 2 some of these collaborations are shown
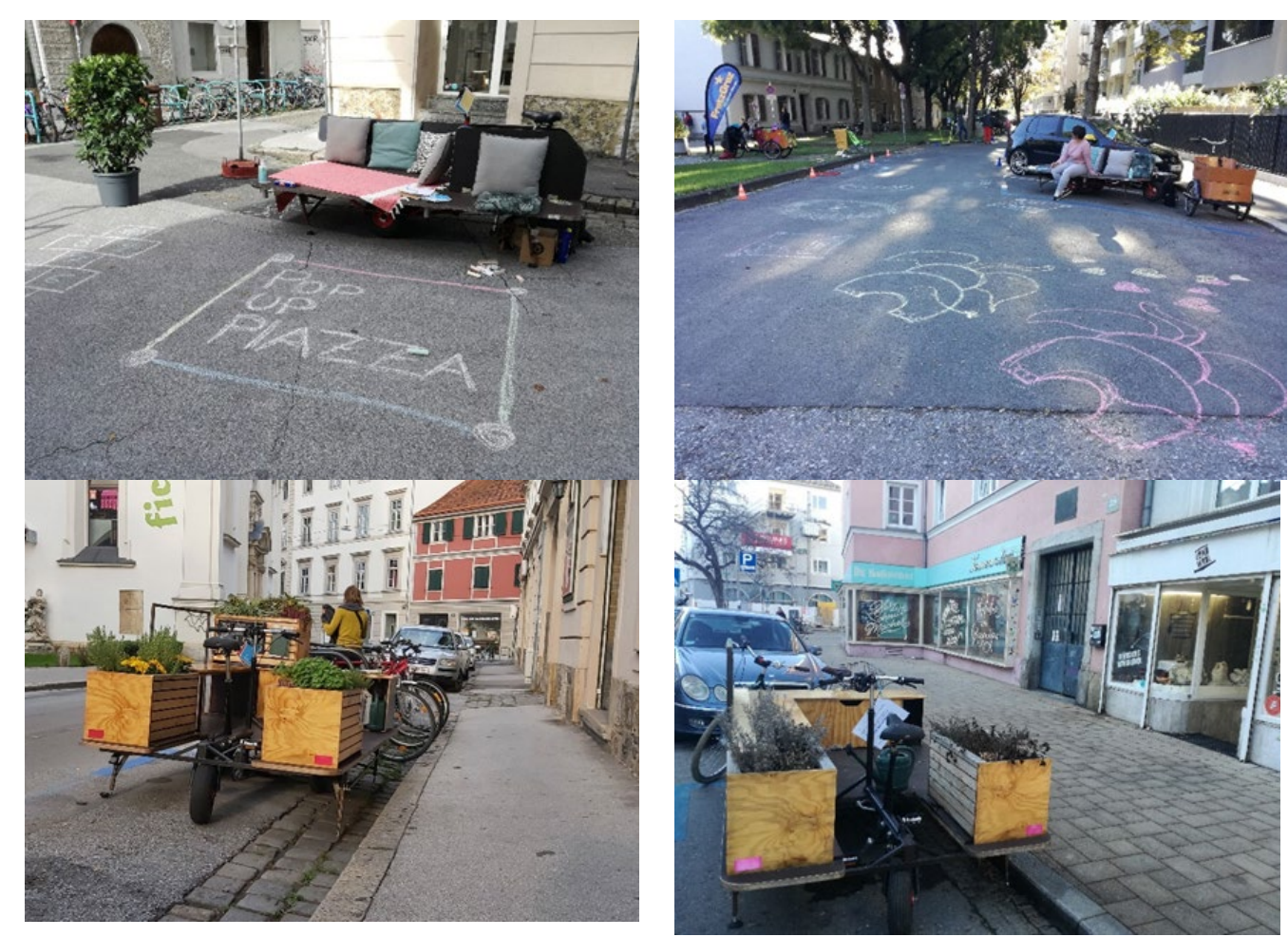

Figure 2: Types of collaborations (from top left to bottom right): joint play of temporary play streets and residential streets with the "space-transformer"; host system - here: "Garden Mobile" hosted by a neighborhood center and a local store (own images, 2020/21) 
Based on the experience of the pilot tests in residential streets in Graz, it can be concluded that the Pop-up Piazza project can make an important contribution towards raising awareness. On the one hand, many passers-by asked about it, were interested in the idea and gave positive feedback about creating a lounge "on the doorstep". However, there have also been many violations of the prohibition of passing through the street, which is set out in the road traffic regulations. However, these could be made aware of their misconduct through the campaign and above all through the targeted playing on the street - which is expressly permitted in residential streets. Here, with a little support, the street space was reclaimed by children.
In addition, the residents were able to enjoy the benefits of the traffic-calmed area and were made aware of it.

In this case, it was particularly evident from the traffic count how important it is to conduct awareness work (see table 3 ). It should be noted that drivers of cars or motorized two-wheelers are not fully aware of the special regulations for residential streets or ignore them. In both survey periods, there were numerous violations of the road traffic regulations. One can even speak of a vicious circle here, since this traffic in turn creates an unsafe environment and as a result children of residents are not allowed to play on the street at all [20].

Table 3: Traffic count results of the pre-survey and the survey during

the intervention in the residential street (Muchargasse) in Graz.

\begin{tabular}{|c|c|c|}
\hline Survey & $\begin{array}{c}\text { 25 July 2020 (4-5pm) } \\
\text { (before intervention) }\end{array}$ & $\begin{array}{c}\text { 22 September 2020 (4-5pm) } \\
\text { (during intervention) }\end{array}$ \\
\hline $\begin{array}{c}\text { Trassenger cars (of which passed } \\
\text { through) }\end{array}$ & $15(7)$ & $37(23)$ \\
\hline Pedestrians & 72 & 123 \\
\hline Cyclists & 36 & 150 \\
\hline Motorcycles & 0 & $6(5)$ \\
\hline Skateboarders & 2 & 3 \\
\hline
\end{tabular}

In addition to pilot testing in residential/playground streets, the host system has also proven to be viable (meaning the use of space provided by third party hosts such as stores). Hosts provide some sort of care/surveillance for the space-transformers, which limits vandalism and littering. Experience has shown that space-transformers that have been "released" have been violently moved or even intentionally damaged a few times. So if someone is monitoring it on the side, there is more security. It also takes away a barrier. This is because many passersby do not perceive the space-transformer as a public space and do not know that they are allowed to use it without further ado. Good experiences have therefore been made especially when the cargo bike transforms car parking spaces into recreational areas in cooperation with district centers or neighborhood offices. These can actively use the space as part of their activities.

One inhibiting factor, especially in Graz, is the administrative framework. Although it is legally permitted to park cargo bikes in a parking lot if they meet certain points, the general approach of the authorities is not to allow this. The restrictive nature of the road authorities makes such implementations in Graz considerably more difficult.

The implementations in Vienna took place mainly within the framework of organized events. During the summer months, 18 street(-sections) in Vienna were temporarily transformed into so-called "Coole
Straßen" ("Cool Streets"). The project is a heat adaptation measure. It is intended to allow cooling in the middle of the city as well as to create free space for the residents. Based on the Vienna heat map, locations were selected that are particularly affected by the heat. The age of the population was also taken into account here, as older people and children have a lower tolerance for heat. During implementation, there was a ban on driving, stopping and parking cars, and instead there were water sprinklers, plants and seating areas. Children were able to use the freed-up space for playing, and adults were also given a place to stay. Bicycling was still possible [17]. The StreetFormator, in this case the playing bike, was also used for the "Cool Street". It brought various toys and sports equipment to the "place of action" and thus took over an important supplementary function for temporary traffic relief. Figure 3 shows the enormous change in the streetscape that can accompany such a temporary transformation. The space, which is normally occupied to a very large extent by stationary traffic, is opened up to people in this scene.

The positive feedback from the supervisors and the results of the observations show that the playing bike primarily fulfills a transport function. In addition to the shady function of the integrated sunshade, the cargo bike itself is occasionally used for climbing attempts by younger children, its table 


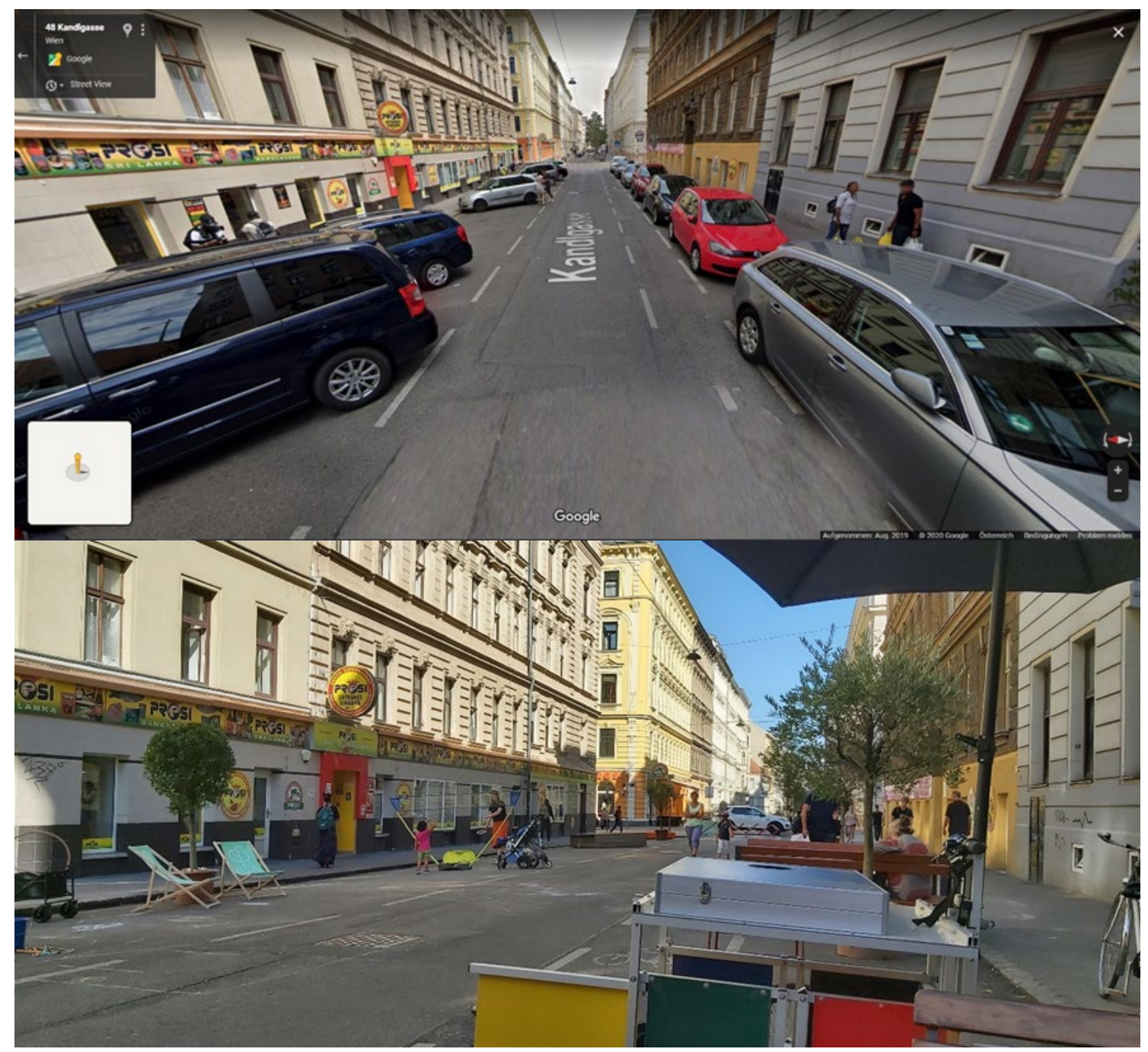

Figure 3: Street section (Kandlgasse) in Vienna before and after the intervention ("Cool Street") (Sources: Google StreetView; Sara Bafaro 2020

proved practical, e.g. for painting, but the greatest attention was focused on the toys brought along, which were very well received. The bike itself was in the background during use and thus fulfilled more of a supplementary function. In this case, it is "only" a means to an end, which is limited here, as previously mentioned, to the transport activity for toys. It transforms the space only indirectly. However, the fact that the street section is officially closed contributes to the transformation much more. In this case, the StreetFormator as a cargo bike that brings the games is a good complement to the road closure to make the most of it [20]. So when the StreetFormator is used in the context of an event, the scope of the evaluation is extended from the prototype to the environment. In this case, it also makes sense to analyze the impact evaluation of the event or action. The evaluation of the "Cool Streets" campaign shows that the general acceptance is high. This is also reflected in the approval of a repetition, although it should be noted that there are differences depending on the location. Most of the people who use the open spaces that have been created come from the immediate neighborhood. The majority visits the Cool Streets with family members, friends or relatives, but many also come alone. In addition to resting, relaxing or chilling out, a quarter of respondents use the opportunity to meet other people. In addition, nearly half of all respondents say they now spend more time outdoors. This shows that the campaign provides an opportunity for people to use public space. The survey results show that the "Cool Streets" also have a social impact. It brings people together in their district and offers them the opportunity to compensate for the lack of private or semi-public open spaces and to use the street as a meeting and communication place [21].During our surveys in Graz and Vienna (both by means of observation and interviews), we were able to conclude that the majority of the people involved (both active users and passers-by) reacted positively to the StreetFormators. Few people expressed rather negative opinions about the action. Often they felt 
disturbed by the event in general or worried about the stores, which were now less accessible by car. The same applies in general to the elimination of parking spaces. A small number of passers-by felt adversely affected by the loss of parking spaces. Those affected often expressed emotional feelings about this, which shows that the topic of removing parking spaces is a very sensitive one. Here it is particularly important to "pick up" these people, i.e. to involve them from the very beginning and to raise their awareness. A top-down approach will not be very promising in such situations. Overall, however, the benefits of the additional public space outweigh the disadvantages. In many cases, the desire for longer-term traffic calming, greening and reuse of the street space is expressed. From the evaluation and interim results to date, adjustments could be made. For example, the findings from the first test phase were incorporated into the design of the remaining StreetFormators still under construction: In the case of the "Meet \& Greet
Bike" (see figure 4), seating is attached directly to the cargo bike so that it can be used directly.

In addition, add-ons were planned that can be installed relatively flexibly, depending on the purpose/location. In addition to redesign measures, "supervised play" of the StreetFormator could also contribute to more interactions with the bike itself. This approach is difficult to implement in times of pandemic with the associated distance regulations but could be the key to success in a normal situation (when people can interact more with each other again). Also, previous deployments had shown that a certain familiarization phase was needed for the space-transformers (in particular the "playing bike" and its equipment) to be accepted and used. In retrospect, the StreetFormator's deployment period of one week per location was considered to be too short. Therefore, a period of at least 2 - preferably 3-4 weeks at the same location is planned for future pilot test actions [20]. (Fig. 4B).

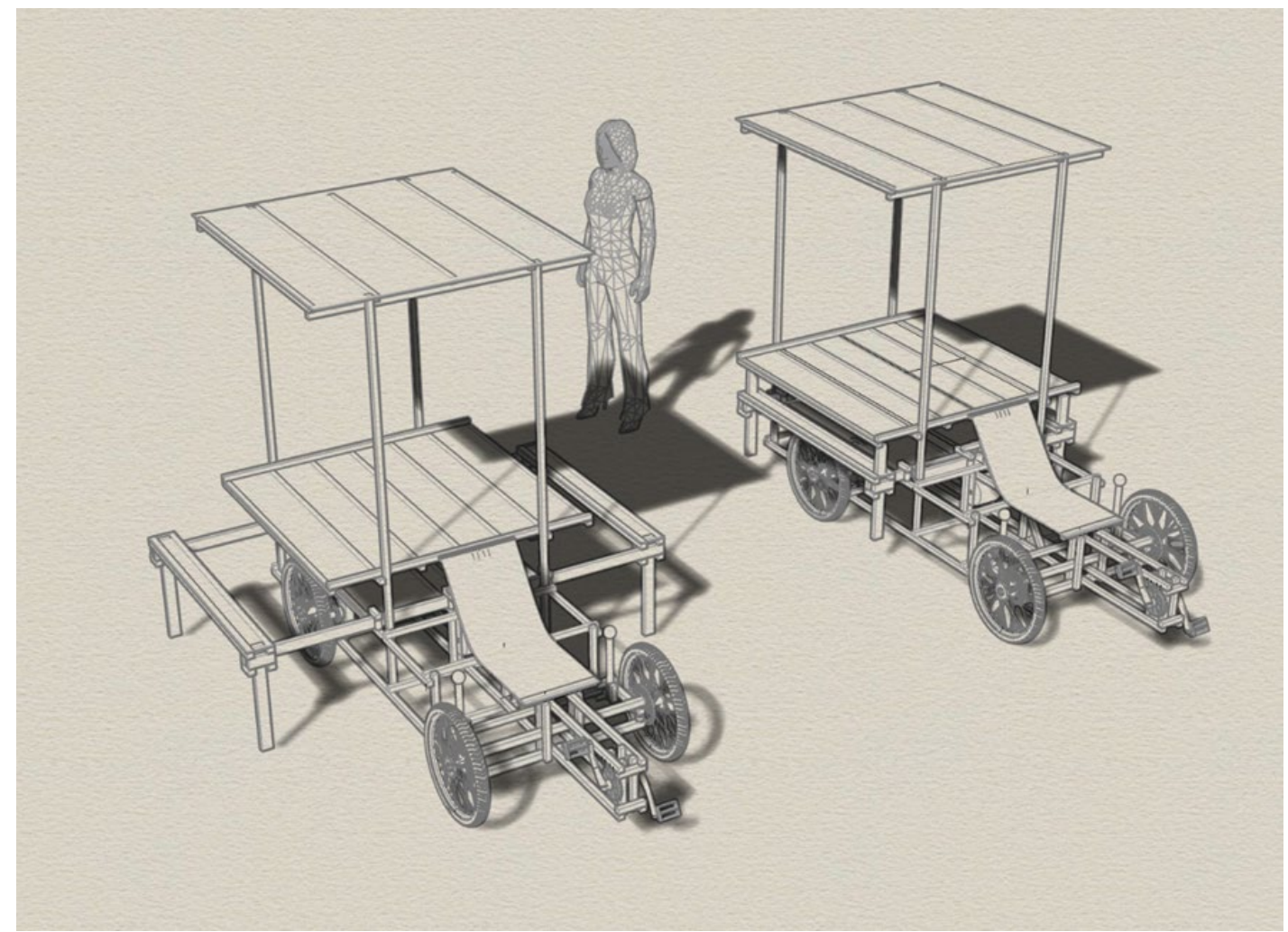

Figure 4: Planning sketch of the StreetFormator named "Meet \& Greet Bike" (Source: xyz cargo 2020

\section{CONCLUSION}

Public street space is clearly not equally accessible to all. The stationary use of cargo bikes therefore has a high potential in urban space. The cargo bikebased tool (space-transformer or StreetFormator) tested in the Pop-up Piazza project is suitable for transforming a car parking lot and transforming the space so that it can be used by more people. The pilot actions attracted attention and raised awareness on the topic. Traditional realities were broken, and thought was stimulated. The framework conditions contribute strongly to the success of the actions, for example restrictive administrative units can delay the actually fast popup transformations. Settings also determine impact. The StreetFormator tends to be in the background when used in a closed street (sparse interaction and hardly noticed) but can complement it well when it "brings" useful add-ons. If only one parking space 
is transformed by the StreetFormator, the focus is more on it and it is then also used more. For this, however, it is advisable to remove barriers as far as possible. Hosting comes into question for this. In addition to host partnerships with associations and businesses, cooperation with private individuals could be considered for the remainder of the project. Experience so far has shown that a bottom- up approach is advisable. Finally, it should be noted that the case studies of Vienna and Graz have shown that the temporary transformation of public street space creates more spaces for people to spend time in public areas, more space for social interaction, a safer area for children and a morepeople friendly environment.

\section{REFERENCES}

[1] OECD (Ed.). The Metropolitan Century: Understanding Urbanisation and its Consequences, OECD Publishing, Paris. 2015.

[2] Holden, E. \& Gilpin, G. \& Banister, D. Sustainable mobility at thirty, Sustainability, 11(7), p. 1965, 2019.

[3] Norton, P. Of love affairs and other stories. In: S. Zavestoski \& J. Agyeman (Eds.), Incomplete streets. Processes, practices, and possibilities, pp. 17-35, London \& New York, 2015.

[4] Lydon, M. \& Garcia, A. Tactical urbanism: Short-term action for long-term change. Washington, 2015.

[5] Furchtlehner, J. \& Lička, L. Back on the Street: Vianna, Copenhagen, Munich, and Rotterdam in focus, Journal of Landscape Architecture, Vol. 14, p. 72-83, 2019.

[6] ORF (Ed.). Fünf Jahre Begegnungszone Graz: Unfälle halbiert. 2016. https://steiermark.orf.at/v2/news/stories/2802854/ (accessed at 8 February 2021).

[7] Bertolini, L. From "streets for traffic" to "streets for people": can street experiments transform urban mobility?, Transport reviews, vol. 40, pp 734-753, 2020.

[8] Talen, E. Do-it-Yourself Urbanism: A History. Journal of Planning History, Vol. 14, p. 135-148, 2014.

[9] Lydon, M. Tactical Urbanism 2. Short-term Action - Long-term Change, The Street Plans Collaborative, 2012. https://issuu.com/streetplanscollaborative/docs/tactical_urbanism_vol_2_final (accessed at 8 February 2021).

[10] Silva, P. Tactical Urbanism: Towards an evolutionary cities' approach. Environment and Planning B: Planning and Design, Vol. 43, p. 1040-1051, 2016.

[11] Webb, D. Tactical Urbanism: Delineating a Critical Praxis. Planning theory \& Practice, Vol. 18, p. 58- 73, 2017.

[12] Lefebvre, H. Writings on Cities. Massachusetts, USA: Blackwell Publisher Ltd, p. 250, 1996.

[13] Harvey, D. The right to the city, International Journal of Urban and Regional Research, Vol. 27, p. 939-41, 2008.

[14] Stadt Graz (Ed.). Aufgaben des Referat für Bauplanung. 2021.

https://www.graz.at/cms/beitrag/10292555/7757978/Referat_Bebauungsplanung.html (accessed at 8 February 2021).

[15] Stadt Wien (Ed.). Auszug aus der Geschäftseinteilung des Magistrats der Stadt Wien. 2021. https://www.wien.gv.at/advuew/internet/AdvPrSrv.asp?Layout=geschaeftseinteilung\&Type=K\&Hlayout=\&STELL $\mathrm{ECD}=1995060915103983$ (accessed at 8 February 2021).

[16] Tomasulo, M. (2013): The tale of a tactic: Prologue. 2013. https://medium.com/@cityfabric/the-tale-of-a-tacticprologue-ec58d155aacb (accessed at 8 February 2021).

[17] Stadt Wien (Ed.). "Coole Straßen" sorgen für Abkühlung, 2020. https://www.wien.gv.at/verkehrstadtentwicklung/coolestrasse.html (accessed at 2 February 2021).

[18] Lokale Agenda 21 Wien (Ed.). Grätzloase. Wir verwandeln den Freiraum, 2019. https://www.graetzloase.at/ (accessed at 8 February 2021).

[19] Forschunsgesellschaft Mobilität FGM-AMOR. Projektbeschreibung für Förderungsansuchen des Programmes Mobilität der Zukunft - Pop-up Piazza. In: Kooperative F\&E-Projekte FFG. 2017.

[20] Bafaro, S. \& Senger, M. \& Giesch, M. Zwischenbericht zur Prozess- und Wirkungsevaluierung. POP-UP PIAZZA Erforschung von Transformationswerkzeugen für die temporäre Umwandlung von öffentlichem Straßenraum, 2020.

[21] Tbw research GesmbH (Ed.). Ergebnisbericht. Evaluierung der Aktion „Coole Straßen“ in Wien. Auftraggeber: Magistrat der Stadt Wien, MA 28. 2019 


\title{
RELIEF AND SEDIMENTS OF NIDA RIVER VALLEY NEAR PIŃCZÓW GAP-SECTION - FIRST RESULTS
}

DOI: https://doi.org/10.18509/AGB217-40145f

UDC: 528.94:551.435.14(438)

\author{
Marcin Frączek $^{1}$, Tomasz Kalicki ${ }^{1}$, Piotr Biesaga ${ }^{2}$, Karolina Walczyńska² \\ ${ }^{1}$ Jan Kochanowski University in Kielce, Institute of Geography and Environmental Sciences, Kielce, Poland, \\ marcinfraczek1987@gmail.com,tomaszkalicki@ymail.com \\ ${ }^{2} J a n$ Kochanowski University in Kielce, Institute of Geography and Environmental Sciences, Student Research \\ Group of Geomorphologists ,Zloty Bażant”, Poland
}

corresponding author:

\begin{abstract}
The study area is located in central Poland in the S part of Nida Basin between two elevations: Umianowice marl monadnock and Pińczów Horst. This is the part of a gap-section of the Nida river near Pińczów. Nida is the 2nd order river, tributary of the Vistula river.

The work aims to recognize the relief and the structure of the Nida valley and to establish the chronology and origin of these structures. The results indicate differentiation in the sedimentation on the wide floodplain and in the vicinity of the riverbed.

On the wide floodplain (more than $2 \mathrm{~km}$ ) between Umianowice and Pińczów, based on aerial photo and digital terrain model, (DTM) we can notice remains of the multichannel river system (probably anastomosing river). Based on the historical maps the changes in the development of the riverbed in this area are visible. Nowadays, in the study section, we can observe the meandering river pattern.The A-B schematic geological cross-section was created based on the series of geological boreholes. Based on the field and laboratory detailed sedimentological analysis we can certainly say that the western part of the A-B profile is significantly different from the eastern part (closer to the river). In the western part, we can distinguish more organic deposits (mostly peaty silts and peats), while in the eastern part sediments are more mineral (mostly sands, sands with gravels and sandy silts). These differences in the geological structure could be caused by the distance from the riverbed and and activity of of fluvial processes.
\end{abstract}

Keywords: Nida Basin, morphodynamic processes, large-radius palaeomeander, anastomosing alluvial plain.

\section{INTRODUCTION}

The natural environment of research area is poorly explored ([1], [2], [3], [4] [5]). According to the physical geographic regionalization of the studied area is located in the Polish Upland province (34), the Little Poland Upland sub-province (342), the

\section{AIM OF THE STUDY AND METHODS}

The study aimed to identify the relief and sediments of the area with the use of many fields, on-desk and laboratory methods. On-desk methods consisted mainly in the query of archival materials and the analysis of aerial photos and thematic maps (Fig. 2). During fieldworks, several boreholes were made (Fig. 3) which allowed for detailed recognition of the forms occurring in the field and, as a result, for the creation of a geomorphological map (Fig. 4).
Nida Basin macroregion (342.2) in the central part of the Nida Valley mezoregion (342.25), on the border with the Jędrzejów Plateau (324.21) and the Połaniec Basin (342.28) [1], (Fig.1).

Geological mapping of the Quaternary sediments was performed, which allowed determining the origin and stratigraphy of sediments in the studied area. In the laboratory, several methods were used. Grain size analysis based on sieve method and laser diffraction, loss of ignition (LOI), analysis of calcium carbonate $(\mathrm{CaCO} 3)$ content (Scheibler method) and the $\mathrm{pH}$ value were determined using the potentiometric method. 


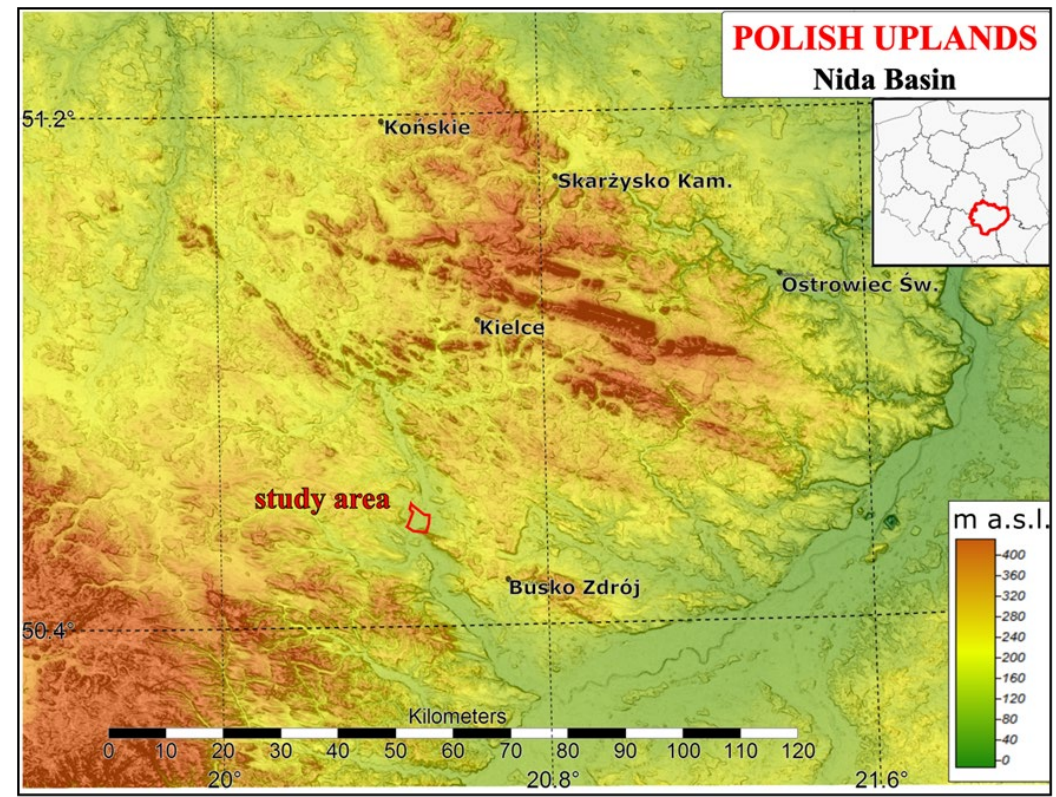

Figure 1. Digital terrain model (DTM) of the Holy Cross Mts. region

\section{GEOLOGICAL AND GEOMORFOLOGICAL BACKGROUND}

The study area is located in the Nida Basin mesoregion, which is a kind of synclinorium between the Kraków-Częstochowa Upland in the west and the Kielce Upland in the north-east [1]. The Nida Basin is filled mainly with Mesozoic formations [2] which were dislocated and covered by the younger Tertiary sediments: marls, limestones, and gypsums, in which karst phenomena developed intensively.

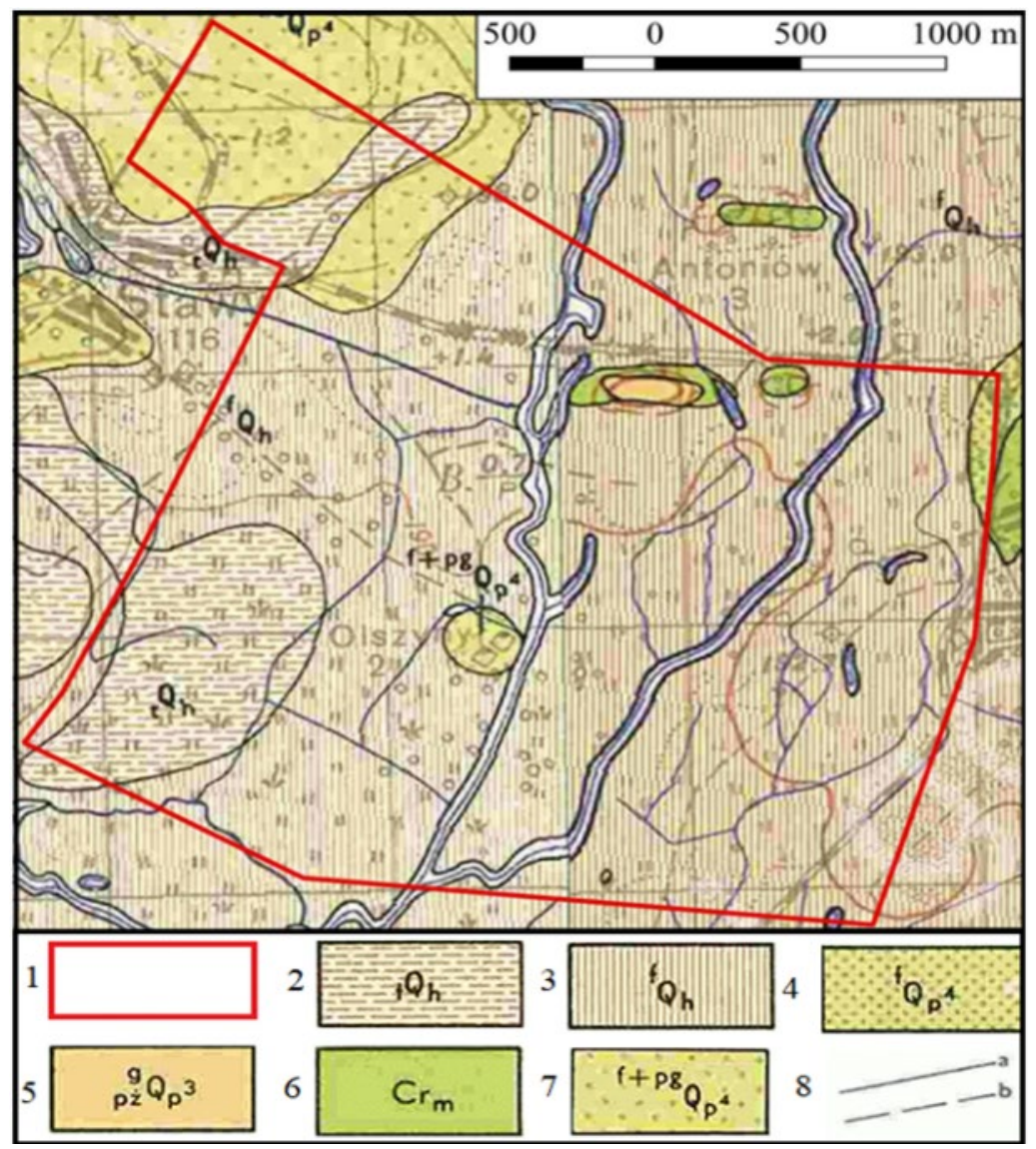

Figure 2. Geological map of the research area based on Detailed Geological Maps of Poland - Jędrzejów [7] and Pińczów [8] sheets 1:50 000; 1 - research area, 2 - peat and peat bogs, 3 - sands, gravels and river meadows, 4 - sands of accumulation terraces, 5 - sands and gravels of glacial accumulation with boulders, 6 - marly rocks, marls, sandstones and geoses, 7 - river-periglacial sands, 8 - boundaries of geological strata; a certain, $b$ - presumed. 
The oldest formations from the Upper Cretaceous Maastricht (marly rocks, marls, sandstones and geoses [2]) formed an erosion socle of the Pleistocene terraces remnants in the flood plain (Fig. 2, 4). The sands and gravels with boulders of the younger terrace were accumulated during the Middle Polish Glaciation (about 440-130 ka [6]). The youngest sediments within the study area came

\section{RESULTS}

The width of study section of the Nida river valley is about $2 \mathrm{~km}$. Two terraces occurred here. The upper terrace is preserved on the right side of the valley. Within the flood plain occurs several erosion remnants of younger terrace.

We can distinguish two levels of floodplain older (cross-section A-B) and younger (outcrop C 1) (Fig. 4). Within older floodplain the schematic geological cross-section A-B was created based on from the Subboreal. Their thickness increases in the southern part of Nida Basin [5] and they are limited to the areas of contemporary river valleys [2]. Sands, gravels, and river marshes, which cover almost the entire research area (Fig. 2), were created as a result of Nida River accumulation. Peats and peaty silts, with the thickness of 1-2 m, represent the Holocene (Fig. 2, 6).

the series of geological boreholes (location Fig. 3, $4,5)$. In their western part, more organic deposits occurred (mostly peaty silts and peats), while in the eastern part (closer to the river) sediments are more mineral (mostly sands, sands with gravels and sandy silts) (Fig. 6). The most characteristic for the western part is the geological borehole Stawy 2 and for the eastern part borehole Stawy 51 .

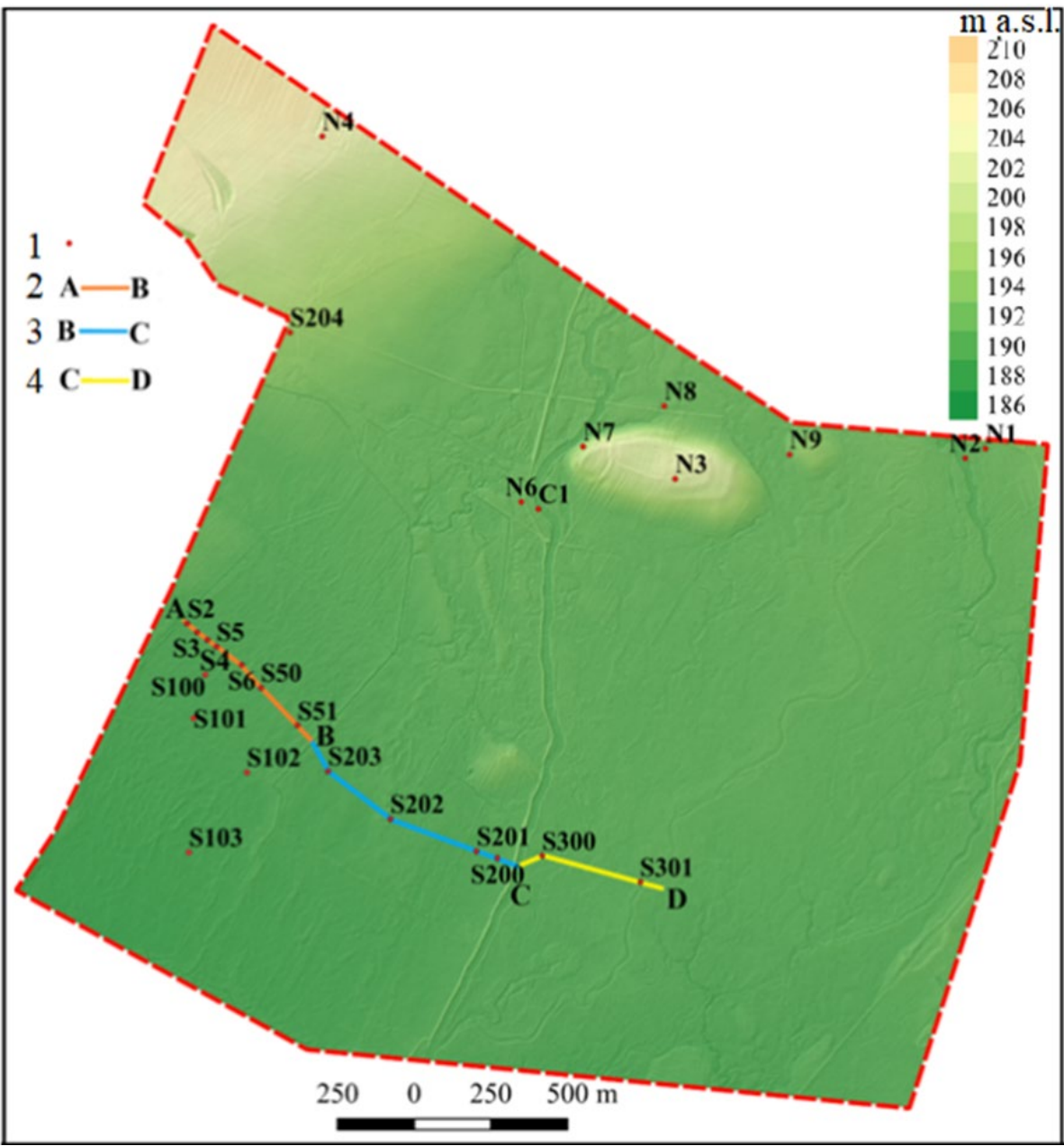

Figure 3. Location of geological boreholes and cross-section lines on DTM 1 - geological boreholes, 2 - A-B cross-section line, 3 - B-C cross-section line, 4 - C-D cross-sectional line.

Four members could be distinguished in the geological core Stawy 2 (Fig. 6 - Stawy 2). The lowest member (I) is built of silty sands (Mz above $4 \phi)$. The second member (II) is built of peaty silts. Organic matter content increases upward from 12 to $38 \%$. The layer of sands (about $5 \mathrm{~cm}$ thick) occurs in the most upper part of this member. The third member (III) is intercalated of silty sands and coarse/medium sands. The sediments of this member are poorly sorted in the lower part and medium sorted in the upper. Four members could be distinguished in the geological core Stawy 2 
(Fig. 6 - Stawy 2). The lowest member (I) is built of silty sands (Mz above $4 \phi$ ). The second member (II) is built of peaty silts. Organic matter content increases upward from 12 to $38 \%$. The layer of sands (about $5 \mathrm{~cm}$ thick) occurs in the most upper part of this member. The third member (III) is intercalated of silty sands and coarse/medium sands.

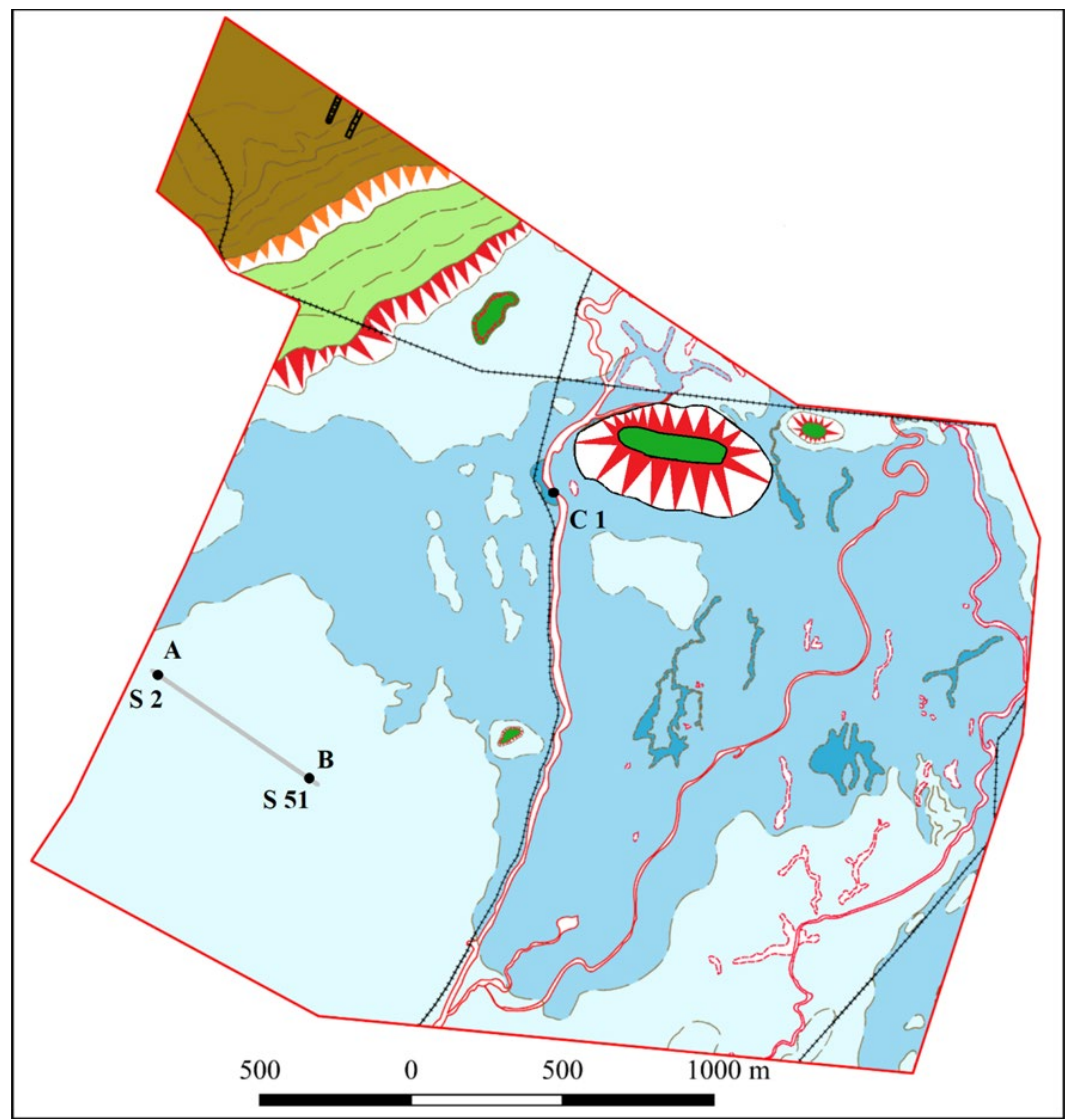

Figure 4. Geomorphological map of the research area; 1 - research area, 2- valley slope, 3 - Pleistocene terrace I, 4 - Pleistocene terrace II, 5 - Holocene floodplain: older cut and fill, 6 - Holocene floodplain: younger cut and fil,

7 - bottom of abandoned channel (organic sediments), 8 - alluvial riverbed, 9 - Holocene abandoned channels,

10 - Holocene edges, 11 - Pleistocene edges, 12 - anthropogenic embankment, 13 - anthropogenic edges,

14 - anthropogenic sunken lane (hollow way), 15 - A-B cross-section line, 16 - No. of geological boreholes.

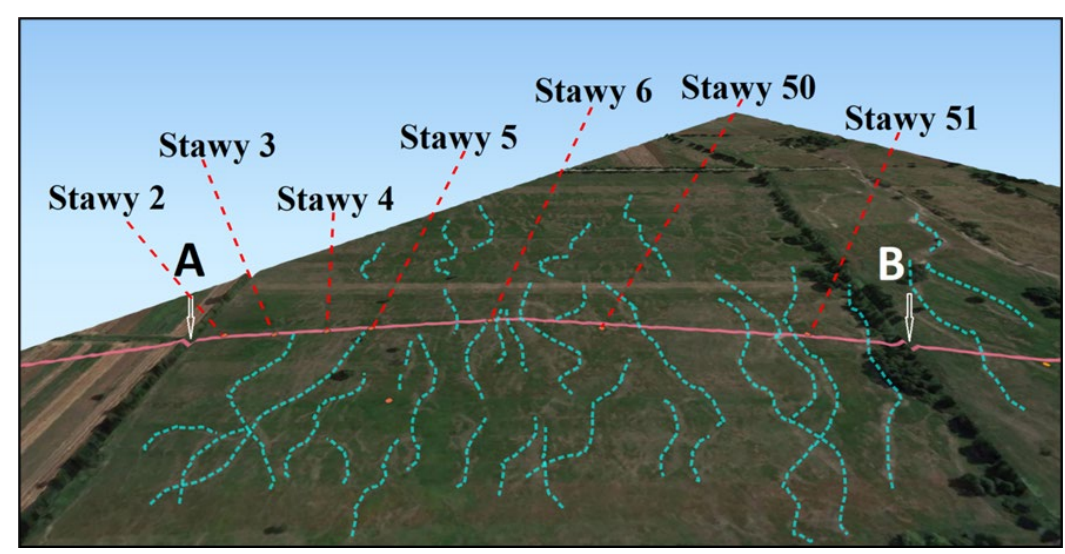

Figure 5. 3D model of Nida floodplain on A-B cross-section distance with remnants of the anastomosing river system

The sediments of this member are poorly sorted in the lower part and medium sorted in the upper. The fourth member (IV) includes peaty silts with an organic matter content from $4 \%$ to $20 \%$. At a depth of up to $29 \mathrm{~cm}$, they are cut with a $10 \mathrm{~cm}$ thick layer of sand. The sand is bad sorted (Fig. 6). The geological core Stawy 51 consists of four members above sandy gravel channel deposits. The first member (I) is built of silty sands bad sorted. The second one (II) is silty peats and peaty silts with organic matter content ranging from 22 to $35 \%$. The third member (III) is mineral deposits (very bad and bad sorted) - silty sands in the most lower and most upper parts and sands in the middle part. The fourth 
member (IV) includes peaty silts with organic matter content from 10 to $18 \%$ (Fig. 6).

The sediments of profile $\mathrm{C} 1$ represents the structure of younger floodplain. There is a typical meandering river alluvium with channel deposits in its bottom and overbank deposits (levee) in the upper part.

\section{DISCUSSION AND CONCLUSIONS}

Remnants of the Pleistocene terrace, that were preserved on the left bank of the valley [10] (Fig. 2, 4) are effect of an intensive deep erosion at the end of Pleniglacial occurred in many Central European valleys of different river orders [11 and references therein].

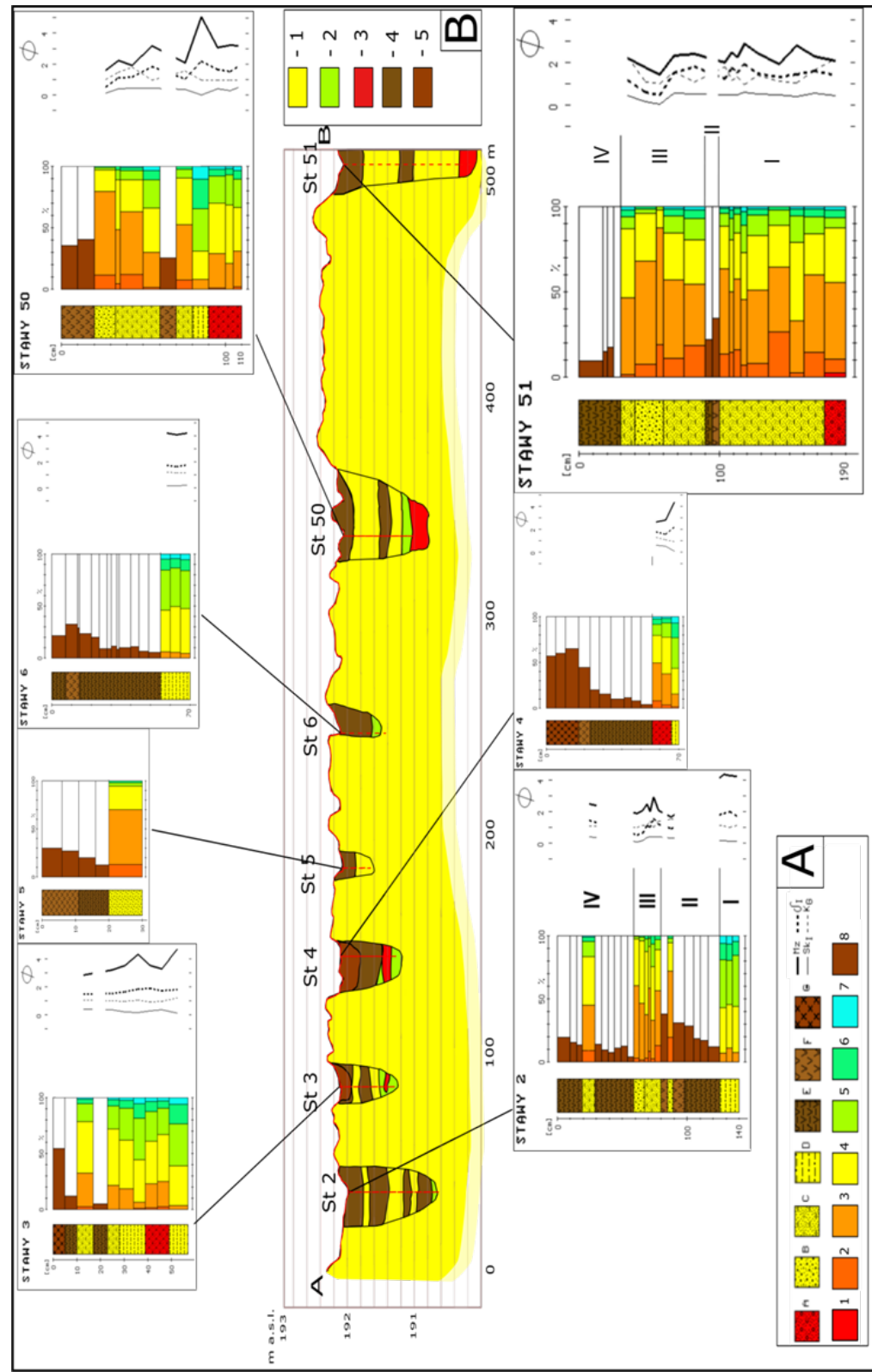

Figure 6. Schematic section A-B (location see Fig. 4, 7) across the Nida floodplain, lithology, grain size and FolkWard's distribution parameters of selected profiles ([2] changed)

A: Lithology: A - gravels, B - coarse/medium sands, C - silty sands, D - sandy clay/silts, E - peaty silts, F- silty

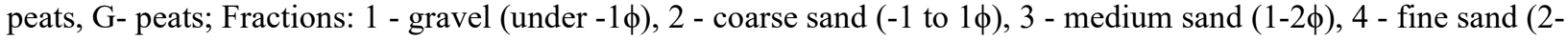

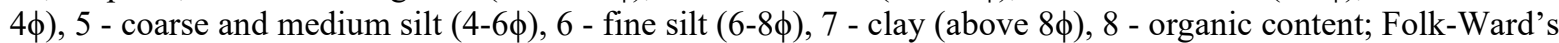
distribution parameters: $\mathrm{Mz}$ - mean diameter, $\delta 1$ - standard deviation (sorting), Skl - skewness, KG - kurtosis. Explanation legend B: 1- coarse/medium sand, 2- sandy silt, 3- sand with single gravels, 4- peaty silts, 5- peats.

Based on the collected materials and mostly on information from other river systems $[12,11$ and references therein], we can preliminarily assume that initially, in the Late Glacial, the Nida was a braided river, then, as a result of the climate change, it was transformed into a river with macromeanders. Upstream of the described gapsection, on the left bank of the Nida floodplain, 
there are visible palaeomeanders (probably largeradius - not clear yet). Within the floodplain occurs several elevations which were earlier considered as dunes [9]. However, there are the erosion remnants of younger terrace. It could be connected with the lateral migration of the Late Glacial large meanders when the valley bottom widened and undercut terrace fragments that were preserved as meandering hills just like it took place in the Czarna Nida River valley [12]. Oxbow lakes visible in the relief of the floodplain reflect lateral migration of the Nida riverbed also during the Holocene.

The peaty plain marked by [9] does not exist in the valley bottom. Geomorphological mapping allowed to distinguish two levels (cut and fill) of the floodplain (Fig. 4).

The older one (cross-section A-B) was formed by an anastomosing river. These small depressions, visible in the relief and on the aerial photo and DTM models, are probably remnants of the anastomosing river system [13]. The geological cross-section confirms the existence of the remnants of the multichannel system (anastomosing).

The abandoned channels are separated by sandy ,islands”. In the palaeochannels, sandy sediments were deposited and during the sedimentological hiatus, organic sediments were deposited (Stawy 2 member III). Sometimes (in short periods) took place a reactivation of this palaeochannels. During the flood episodes badly sorted sands were deposited (Stawy 2 member III and IV, Stawy 51 member I and III). Closer to the presentday riverbed the mineral sediments in the paleochannel fill prevail while organic sediments dominate as the distance increases.

The similar remnants of multichannel patterns are preserved in relief of many sections of the Czarna Nida River valley (a left tributary of the Nida) and they were active in the Early (PB-BO) and Late Holocene (SA-2) [12].

The younger cut and fill of Nida are connected with the meandering river (outcrop C 1) where on the channel sediments we can find overbank deposits (levee). Upstream the described gap-section, on the left bank of the Nida floodplain, there are visible two old Nida River branches. Their presence could be caused by an anthropogenic or the natural processes [13]. Within the research area, there are several different ages sequences, which were formed by a river with different channel pattern. These episodes have not yet been precisely identified and require further detailed research.

\section{REFERENCES}

[1] Kondracki J., Geografia regionalna Polski, PWN, 2012.

[2] Łyczewska J., Objaśnienia do szczegółowej mapy geologicznej Polski,1:50 000, Arkusz 883 Jędrzejów, Wydawnictwo geologiczne, 1971.

[3] Pożaryski W., Rozwój poglądów na tektonikę Niżu Polskiego. W: Budowa geologiczna Polski, 4 - Tektonika, part 1, 35-44, 1974.

[4] Stupnicka E., Geologia regionalna Polski, Wydawnictwo Geologiczne, Warszawa 1989.

[5] Kupczyk E., Biernat T., Ciupa T, Kasprzyk A. and Suligowski R., Zasoby wodne dorzecza Nidy. Wyd. WSP, Kielce, p. 175, 1994.

[6] Lindner L., O podziale klimatostratygraficznym kompleksu środkowopolskiego w plejstocenie Polski, Przegląd Geologiczny, 36-45, 2012.

[7] Łyczewska J., Szczegółowa mapa geologiczna Polski arkusz 883 Jędrzejów w skali 1:50000, Wydawnictwa Geologiczne 1972.

[8] Senkowicz E., Szczegółowa mapa geologiczna Polski arkusz 884 Pińczów w skali 1:50000, Wydawnictwa Geologiczne 1958.

[9] Mityk J., Zarys rzeźby terenu badanego odcinka zlewni Nidy, Studia Kieleckie 1/61, Kielce: 21-30, 1989.

[10] Walczyńska K., Tomczyk M., Geomorphological and morphodynamic mapping of the Nida valley near Stawy. 24 Kvarter, 30 listopada 2018 Brno, 69, 2018.

[11] Kalicki, T. Zapis zmian klimatu oraz działalności człowieka i ich rola w holoceńskiej ewolucji dolin środkowoeuropejskich (Reflection of climatic changes and human activity and their role in the Holocene evolution of Central European valleys). Prace Geograficzne 204, 1-348, 2006.

[12] Krupa J., Naturalne i antropogeniczne procesy kształtujące dno doliny Czarnej Nidy w późnym vistulianie i holocenie, Folia Quaternaria 81, 1-174, 2013.

[13] Walczyńska K., Rzeźba i osady równiny zalewowej Nidy w okolicach Umianowic. Typescript of Bacalar work. UJK archives, Kielce, 2019 


\title{
PALEOENVIRONMENTAL STUDY OF OUM ALI REGION (TÉBESSA, ALGERIA) DURING QUATERNARY, THROUGH THE STUDY OF FLUVIAL TERRACE OF KHENIGUE WADI
}

DOI: https://doi.org/10.18509/AGB217-40153n

UDC: 551.435.7.07:528.526.1(65)

\section{Defaflia Nabil $^{1}$, Djaiz Fouad ${ }^{2}$, Fehdi Chamseddine ${ }^{3}$}

\begin{abstract}
${ }^{1}$ Université Larbi Tbéssi de Tébessa, Faculté des Sciences Exactes et des Sciences de la Nature et de la Vie. ${ }^{2}$ Université Mostefa Ben Boulaid Batna 2, Institut des Sciences de la Terre et de l'Univers, Dépt. De Géologie. ${ }^{3}$ Université Larbi Tbéssi de Tébessa, Faculté des Sciences Exactes et des Sciences de la Nature et de la Vie.
\end{abstract} corresponding author: defaflianabil@yahoo.fr

\begin{abstract}
Stratigraphic, sedimentological and magnetic study was performed on alluvial terraces, rich in archaeological tools, the region of OUM ALI, in north-eastern Algeria. The sedimentological points of view, the sediments are dominated by the sand fraction followed by the silt fraction; moderate concentrations of $\mathrm{CaCO} 3$ are the result of the dissolution of the surrounding limestone reliefs (Maastrichtian limestone). The morphoscopic observation of quartz grains with a dissecting microscope allows us to offer more or less significant changes, since they are often dull or sub-blunted.

The results of the magnetic survey are consistent with those of the sedimentological study. The values of magnetic susceptibility are strong in the middle part of the stratigraphic section (just above the archaeological level) and decrease slightly at the top. Lower values are stored in the lower part. The dependence of frequency values of magnetic susceptibility ( $\square \mathrm{fd}$ ) are strong throughout the stratigraphic section and show the presence of a mixture of single-domain grain size (R), pseudo-single domain (PMD) and superparamagnetic (SP) (with a predominance of SP grains). The high concentration of SP grain size reveals the presence of significant soil formation during the implementation of the sediment.
\end{abstract}

Keywords: Oum Ali, fluvial terraces, Quaternary, Magnetic susceptibility, Late Pleistocene, Holocene.

\section{INTRODUCTION}

The site of Oum Ali is located to the south of the city of Tébessa, located at 250 kilometers from the Mediterranean Sea. It is bordered to the north by a chain of mountains of medium to high altitudes (Jebels Doukkane, Anoual and Bouroumane) (Fig.1). The present work is to study stratigraphic, sedimentological and magnetic (magnetic susceptibility) of Quaternary sedimentary formations of alluvial terraces at Oum Ali area in order to better characterize paleoenvironmental characteristics, especially the climate in the prehistoric period from the Aterian during Neolithic. The area of Oum Ali, is located on the edge of the Algerian-Tunisian border and is part of the Saharan Atlas. The reliefs are mixed, consisting essentially of Maastrichtian limestone along a SWNE axis, and separated by a Mio-Quaternary depression (cultivated plain of El Ma El Abiod).

This structure is due to two tectonic phases that have affected the region (Atlas phase -between the upper- Miocene and lower Lutetian, and dated phase of Miocene). The macroscopic field observation allowed the subdivision of the geological section in seven different stratigraphic levels, indexed from 1 to 7 (Fig. 2).

Level 1: is localized between $0-50 \mathrm{~cm}$ (thickness $=$ $50 \mathrm{~cm}$ ).It is formed mainly of gravel and pebbles $(60 \%)$ and roller $(10 \%)$ of white limestone with an irregular shape and jagged edges. The degree of damage is low. The matrix (30\%) is thin and with olive color. The carbonates rate is 39.62 to $46.29 \%$, and the sediment is rich in organic matter (abundance of rosemary roots / absence of human activity traces / abundance of snails debris (= traces animal activity)).

Level 2: localizes between -50 and $-65 \mathrm{~cm}$ (thickness $=15 \mathrm{~cm}$ ).It consists mainly of fine matrix ( $70 \%$ of total), brown olive color (dark), and rich in organic matter. The carbonate content is from 42 to $47 \%$. We notice a few spots, the absence of of human activity evidence and abundance of debris shells (traces of animal activity). Gravel and pebbles $(30 \%)$, whitish calcareous nature have an irregular shape and angular edges, the degree of 
damage is low. The predominance of the fine fraction (clay and silt) indicates a dry climate and low water flow.

Level 3: localizes between -65 to $-90 \mathrm{~cm}$ (thickness $=25 \mathrm{~cm}$ ).It is mainly composed of gravel and pebbles $(60 \%)$ of calcareous nature and whitish, with irregular shape and angular edges, the degree of damage is low.The matrix $(40 \%)$ is thin and olive-colored (clear), it contains $46-47 \%$ of carbonates and is rich in organic matter (plant roots). There is a lack of spot and traces of human activity, and abundance of snail debris (traces of animal activity).

Level 4: locates between - 90 and $-107,5 \mathrm{~cm}$ (thickness $=15 \mathrm{~cm}$ ).It is formed essentially of fine matrix (80\%), brown olive color (dark), and containing little organic matter (traces of roots). The carbonate content is from 51 to $52 \%$. We see the presence of some spot, no trace of human activity and abundance of snail debris (traces of animal activity). Gravel and pebbles (20\%) are whitish calcareous nature with an irregular shape and angular edges.

Level 5: locates between 107.5 and $-123,5 \mathrm{~cm}$ (thickness $=17 \mathrm{~cm}$ ). It is mainly composed of gravel

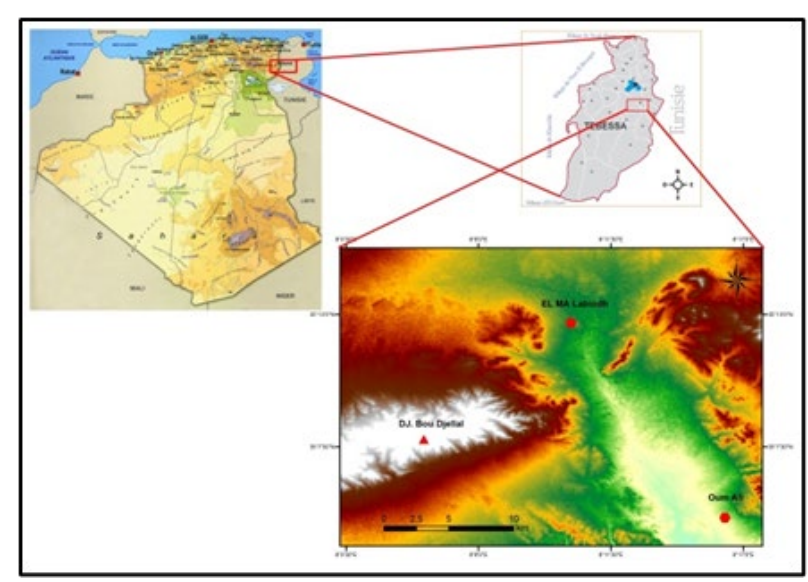

Figure 1: Geographical situation of Oum Ali site Tébessa, Algeria

\section{METHODOLOGY AND MATERIAL}

In the laboratory, two types of analyzes were undertaken:

\subsection{The sedimentological analysis}

They include the size analyzes, dosage of carbonates and morphoscopic study of quartz grains and clay mineralogy. Prior to analysis, the raw sample, sieved to $2 \mathrm{~mm}$, was dried in an oven at a temperature of $40^{\circ} \mathrm{C}$. The garnulometry of fine particles was conducted on [1] granulometer with laser diffraction. The sources are a red He-Ne Laser at $632 \mathrm{~nm}$ for the detection of large particles and a and pebbles (65\%), of calcareous nature and whitish, with irregular shape and angular edges. The matrix is fine $(35 \%)$, olive color (clear) and contains 46 to $47 \%$ of carbonates. It is rich in organic matter (plant roots). There is a lack of spot and traces of human activity, and abundance of snail debris (traces of animal activity).

Level 6: localizes between -123.5 and $-147 \mathrm{~cm}$ (thickness $=23 \mathrm{~cm}$ ). It consists mainly of fine matrix ( $80 \%)$, brown olive color (dark), containing some of organic matter (roots). The carbonate content is between 45 and $57 \%$. We see the presence of some spot, no trace of human activity and abundance of snail debris (traces of animal activity) .The gravel and pebbles (20\%), whitish calcareous nature have an irregular shape and angular edges.

Level 7: is localized between -147 and $-176 \mathrm{~cm}$ (thickness $=29 \mathrm{~cm}$ ). It is mainly composed of gravel and pebbles $(60 \%)$, of calcareous nature and whitish, with irregular shape and angular edges. The matrix $(40 \%)$ is thin, olive-colored (clear) and contains 37 to $47 \%$ of carbonates. There is a lack of spot and traces of human activity, and abundance of snail debris (traces of animal activity).

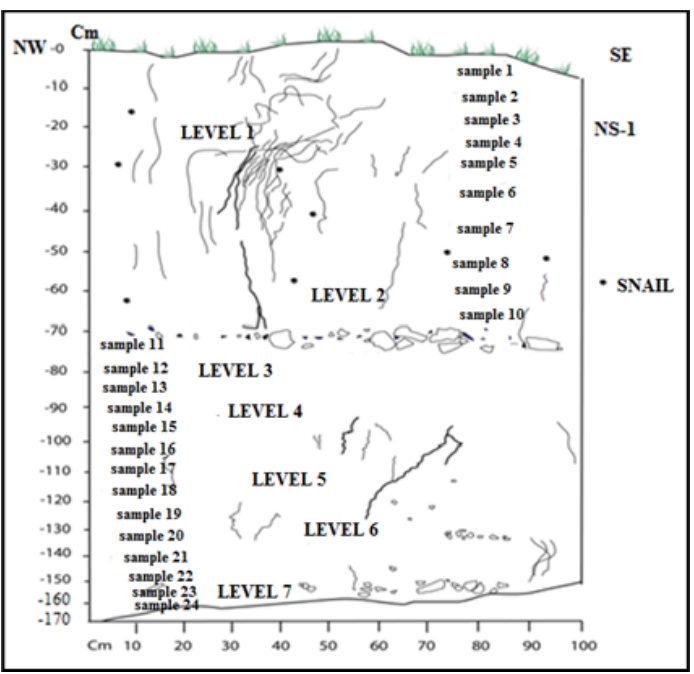

Figure 2: Stratigraphical $\log$ of the studied terrace.

blue LED at $466 \mathrm{~nm}$ for the detection of fine particles. Each sample was analyzed simultaneously wet and dry first on crude fraction and then the same fraction decalcified. For the calculation of parameters and indices of sand, we used the manual granulometer [1] (Mastersizer $\square 2000$ ) and interpretation of the results to the works of [2], [3], [4], [5] and [6]. The various indices are selected those most used during the past decade.

Average: average is called a logarithmic or arithmetic average distribution (according to the 
nature of the abscissa) values of the independent variable. This parameter provides information on the average size of the sample and hence the energy of the environment and transport distance. It is defined by the following formula: $\mathrm{Mz}=(\mathrm{Q} 16+\mathrm{Q} 50$ + Q84) / 3, Mz size and Folk Ward Average

Skewness, Sk : This skewness characterizes the degree of distortion of the symmetry of the distribution. When the skewness is zero, this means that the asymmetry is perfect (median, mode and mean coincide). When it has negative values, it is the fine grains that are highly ranked; positive values correspond to good ranking coarse grains. This parameter reflects better the depositional environment as the conditions of transport.

The Kurtosis: is representative of the sharpness of the peak (width) when it is zero, the curve is called mesokurtic or moderately sized, when it is greater than 0 , the curve is called leptokurtic, this means that the distribution is classified, which is a modal marker at constant power. If the kurtosis is negative, it means that the distribution is misclassified (platykurtic).The morphoscopic study, develop [7] is applied to the quartz grains, decarbonatation in cold conditions of the fraction between 0.5 and $0.25 \mathrm{~mm}$. It is performed using a binocular microscope and it consists to examine the shape and appearance of quartz grains in order to provide information on the transport mode of these grains. The calcimetry was measured systematically. Its consist of the determination of the calcium carbonate percentage on $0.5 \mathrm{~g}$ of ground and dried sediment of less than $2 \mathrm{~mm}$ size, using the Bernard calcimeter.

Concerning clay mineralogy, we used the method developed [8]. The analyzes were performed by Xray diffraction on oriented aggregates. The study of clay mineralogy was performed by a diffractometer equipped with a copper anticathode. The settings are optimized to work in small angles $\left(30^{\circ}\right)$ which

\section{RESULTS AND INTERPRETATION}

\section{1. sedimentological study}

The sedimentological study was performed on 26 samples taken systematically from the top to the base of the stratigraphic section.

The study of the gross particle size fraction smaller than $2 \mathrm{~mm}$ (Fig. 3) allowed to individualize seven stratigraphic levels, some rich coarse fraction (gravel and pebbles) alternating with high levels of silt. The percentage of the clay fraction is very low and remains almost constant almost throughout the stratigraphic section. The particle size of the fine diffract mainly clay minerals. For the determination of clay minerals, the following works were consulted: [9], [10], [11], [12], and [13].

\subsection{Magnetic analyzes}

Magnetic methods allow a- to reveal variations, particularly in the filings, which are not necessarily obvious to the naked eye,

b- to classify different types of materials, c- to identify and transport processes formation of magnetic grains,

d- to propose a paleoclimatic interpretation [14] ; [15]. All magnetic measurements were made on samples of the unoriented, dried and consolidated with an aqueous solution of sodium silicate, in order to prevent movement of the grains during handling. The following magnetic properties were measured:

1-the mass magnetic susceptibility $(\chi)$ : with low frequency $(0.46 \mathrm{kHz})$ and high frequency $(4.65$ $\mathrm{kHz}$ ) was measured with a Bartington susceptibilimetre MS2B MS2 connected to a probe, 2-frequency of the magnetic susceptibility dependence ( $\square \mathrm{fd}$ ): Is calculated from the previous parameter using the formula:. $\left.\chi_{\mathrm{fd}}=\left(\left(\chi_{\mathrm{bf}}-\chi_{\mathrm{hf}}\right) / \chi_{\mathrm{bf}}\right)\right) \mathrm{x}$ $100 \%$ (Maher et al 1986; Maher 1988; Mullins 1977). This parameter specifically detect the presence of small magnetic grains ( $\square 0.03$ microns) showing a superparamagnetic behavior.

3-The procedure proposed by Lowrie (1990) was also applied to some samples. This procedure is based on the analysis of the thermal demagnetization three ARI induced in the laboratory according to three orthogonal axes. We chose a field of $2.5 \mathrm{~T}$ along the axis $\mathrm{Z}$, of $300 \mathrm{MT}$ along the $\mathrm{X}$ axis and $20 \mathrm{mT}$ along the axis $\mathrm{Y}$. This procedure allows highlighting the existence of several populations of magnetic grains which differ in their chemistry or size [16] [17].

fraction (Fig. 3) shows a relatively uniform sediment, with very little clay $(0.69 \%$ on average), a high silt rate $(77 \%)$ and fine sand percentages and coarse moderate (10 and 15\% respectively). They are aware of a development parallel to that of gravel and pebbles. Level 1 , in which the silty fraction increases at the expense of the coarse fraction (coarse and fine sand), is an exception. Within 4 and 5 levels, the proportion of coarse sands increases to the detriment of silt. 


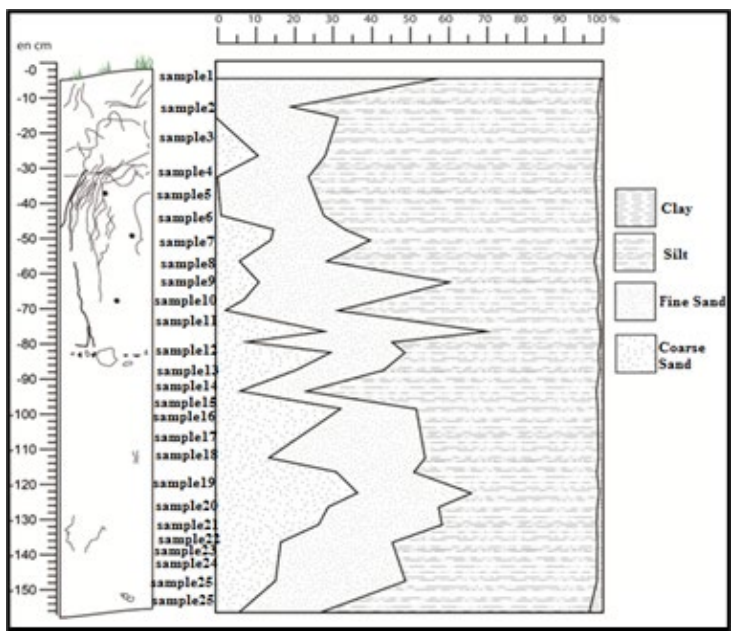

Figure 3: Fine sediments granulometry

\subsection{Grain size characteristics}

The cumulative size distribution curves of gross sand fractions have variable shape. Some cumulative curves are upturned and said facies "parabolic" (Fig. 4). This applies to samples 1 and 2 the upper part of the terrace and corresponds to immature sediments that have not evolved over time and has undergone a redesign transport [6].

The cumulative curves downward facing (hyperbolic facies) (fig. 4) are also present and

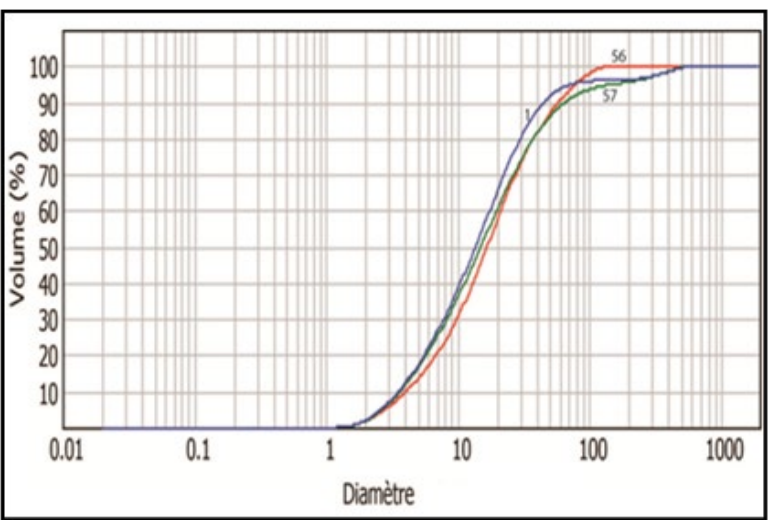

Figure 5: Cumulative curve of specimens 3,56 and 57

After calcining, the curves of the majority of samples did not change their paces and appoint a misfiled sand, except the sample No. 1, which shows a hyperbolic curve (although classified sand) (fig. 6) The median and the other granulometric parameters of this sample decreased, which is due to the enrichment of the carbonate-containing material in material. The average values vary between 10 and 32 (Fig. 7) and relatively low to moderate $(<50$ microns) in all layers. These low values are due to the preponderance of silty sand fraction. The deposition of the fine fraction is relatively well in relation to a rise in water level. Kurtosis of the values range between 0.7 and 1.60 (fig. 7), frequency histograms are type platykurtic

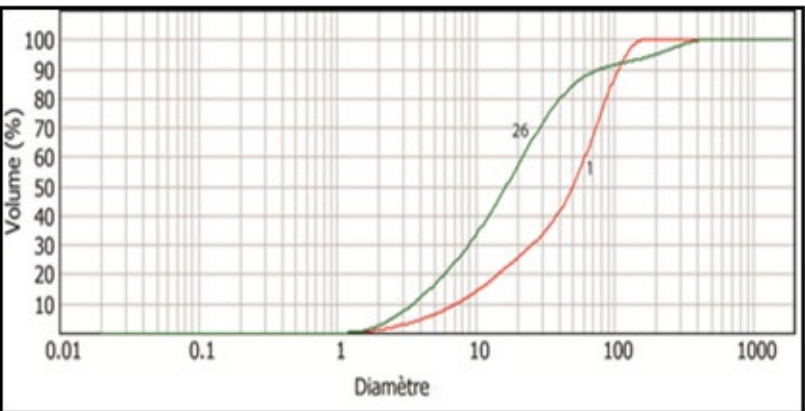

Figure 4: Cumulative curve of specimens 1 and 26

demonstrate a calm environment, sedimentation settling. This type of sedimentation concerns especially the samples 26 and 40 of the middle and lower part of the terrace Some samples show cumulative curves for sub-logarithmic $\log (3,50$ and 51, 53, 57, 59, 60, 63, 64 and 67 (Fig. 5). This is sediment silty dominance which characterizes a medium calm, which are deposited by excess load upon reduction of the speed of transport..

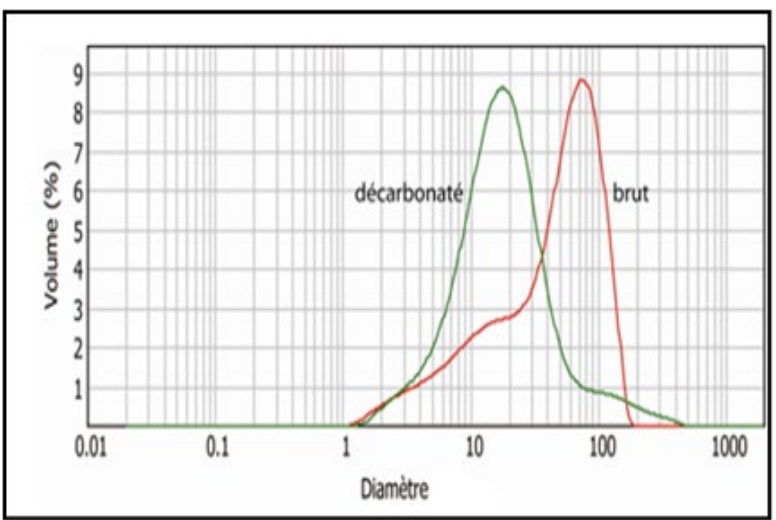

Figure 6: Frequency curve specimen $\mathrm{N}^{\circ} 1$ (brut and decarbonated).

to mesokurtic sometimes leptokurtic. This evolution and shows the presence of a low ranking sediment levels and others to average to good ranking. Indeed, when Coulter indicated that a curve is platykurtic, it happens that certain methods of fine sands are indicated as leptokurtic but because platykurtics associated with silts and clays very misclassified.

The skewness values are negative or close to zero (Fig. 7), they show that the spread of the histogram is the side of the fine fraction. In other words, the ranking is better on the side of coarse elements that the side ends. The ternary diagram shows that sediments consist mainly of silt and sand with silt dominant in the upper part (Fig. 8). 


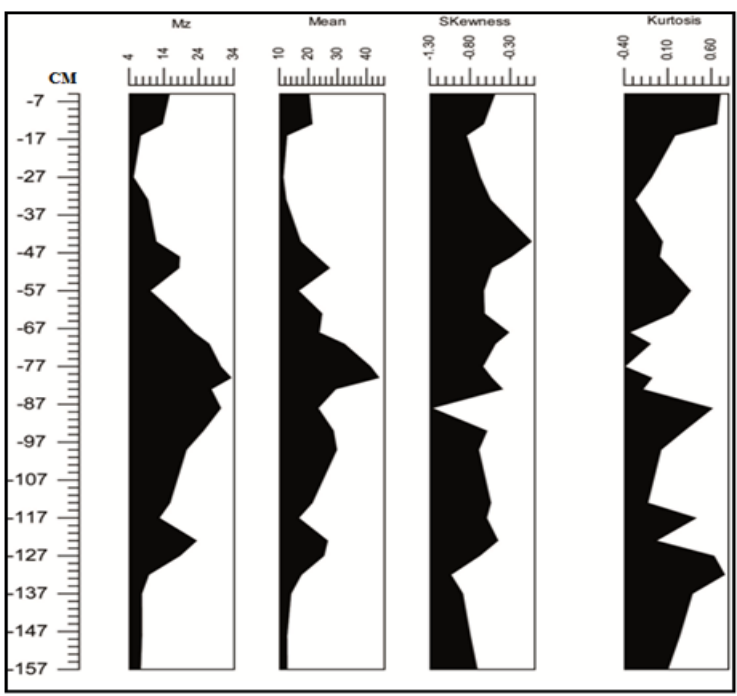

Figure 7: Result s of different size index

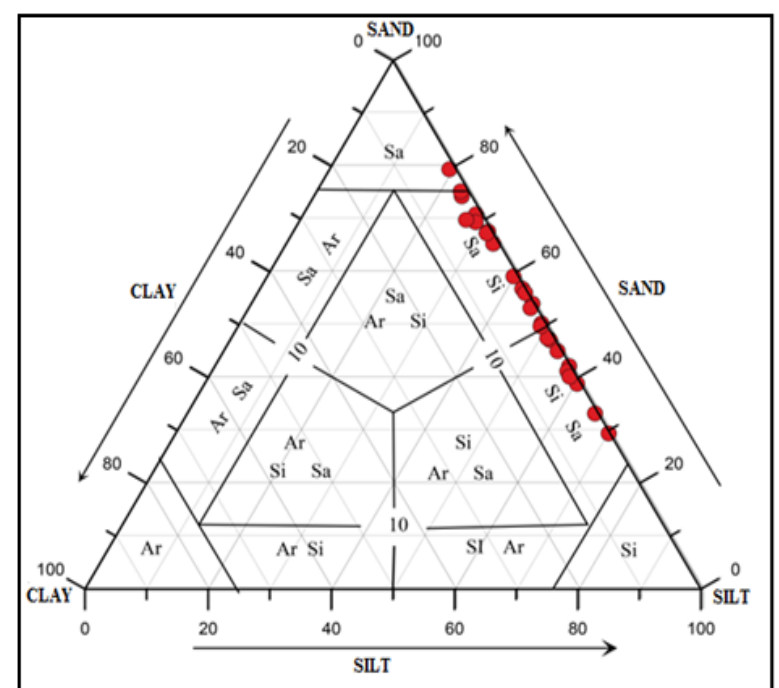

Figure 8: Ternary diagram of the granulometric denomination of the fine sediment

quartz grains could have originated Miocene sand, very present in the region. The presence of a coating on some ferruginous grains indicates the beginning of a soil formation. The unworn (UN) have a low percentage $(17.65 \%)$. The presence of these grains reflects a source of near intake, with unsophisticated sediments.

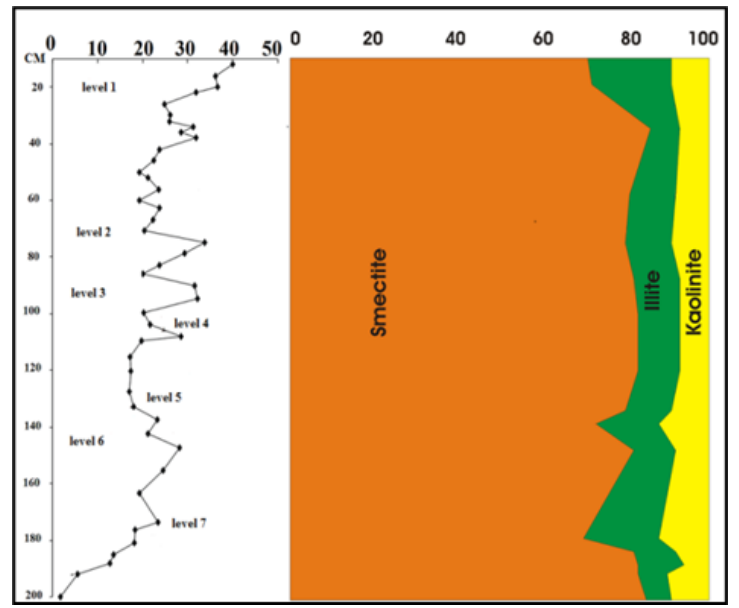

Figure 10: XRD Diffractograms of levels 1.2 to 7

well crystallized. Kaolinite, indicated by the natural peaks: $7.14^{\circ} \mathrm{A}(001)$ and $3.57 \mathrm{~A}^{\circ}(002)$ (fig. 10). It is $23.64 \%$ on average. The contents are not homogeneous throughout the cut. The highest levels $(24.58 \%)$ are recorded in the level $\mathrm{E}$ and the contents are low in level D $(18.75 \%)$. The crystallinity of this mineral is also perfect. Illite is shown by natural peaks: $7.14 \mathrm{~A}^{\circ}(001)$ and $3.57 \mathrm{~A}$ $\circ$ (002), and its disappearance after heating at $90 \%$. It represents ( $7.53 \%$ on average). The contents are homogeneous throughout the cut. This mineral does not have good crystallinity. The origin and clays forming conditions are diverse. Thus, illite is 
formed in cold climates and / or dried [9] [18] [19]. It comes from the weathering of silicate rocks.

Smectite is formed in large quantities under the action of a hot climate with alternating wet and dry phases [19]. Smectite is a fairly common mineral in

\subsection{Magnetic study}

The values of the magnetic susceptibility are strong in the middle part of the stratigraphic section just above the archaeological level (fig. 11) and decreased slightly at the top. Lower values are stored in the lower part. The dependence of frequency values of magnetic susceptibility ( $\square \mathrm{fd}$ ) are strong throughout the stratigraphic section and show the presence of a grain size mixture MD, PMD and SP (with a predominance of SP grains). The high concentration of SP grain size reveals the presence of significant soil formation during the implementation of the sediment. Results for calcimetry are fairly homogeneous (Figure 11), with an average content of $32 \%$ carbonate (14 to $46 \%)$. However, their percentages are increasing at the same levels as the coarse fraction (gravel and stones) and coarse sand register moderate proportions. It is therefore possible to think that these three fractions have the same origin. We believe that some of these limestones are synsedimentary and could precipitate from the dissolution of the surrounding limestone reliefs

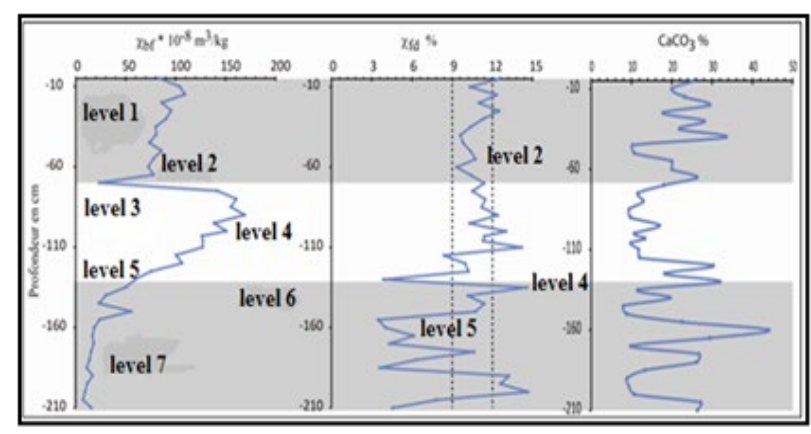

Figure 11: A; Magnetic susceptibility.

B; Frequency dependent magnetic susceptibility (\%). $\mathrm{C}$ : Percentage of $\mathrm{CaCO} 3$.

\section{CONCLUSION}

The parameters obtained from these results (particle size, rock magnetism, and clay mineralogy and crystal grain morphoscopy). Allow the subdivision of the terrace of Oum Ali in 7 stratigraphic levels. The particle size results indicated that the sediments have a weak (less than 50 microns), which is due to their enrichment in silt and fine sand. The frequency curves are platykurtic type mesokurtic sometimes leptokurtic. This development shows the low ranking of the analyzed sediments. Values $\mathrm{KG}$ (kurtosis) are negative or close to zero and show that spreading of the curve is on the side of the fine fraction. Sorting The index values show that sedimentary systems making its interpretation difficult. In the Mediterranean, it is mainly provided by the rivers and wadis. Kaolinite is the most abundant in hot and humid climate, runoff or drainage ensures the evacuation of ions.

(Maestrichtian limestone).

The test [16] allows studying the different coercivity families present in the fill. A sample $\left(\mathrm{n}^{\circ}\right.$ 12) has been subjected (Fig. 12). The principle of this test is the thermal demagnetization in zero fields, up to $700^{\circ} \mathrm{C}$, the sample according to three components of coercivity. The study of families in low coercivity is performed along the $\mathrm{X}$ axis, compared to medium coercivity along the $\mathrm{Y}$ axis and those of high coercivity along the axis $Z$. This test determines the Curie temperatures for different population's together time. These release temperatures are represented by slope changes corresponding to the magnetic remanence of losses of minerals. The presence of hematite $\left(680^{\circ} \mathrm{C}\right)$ and goethite (between 80 and $120^{\circ} \mathrm{C}$ ) (fig. 12) has allowed to estimate the average annual temperature and soil moisture at $17^{\circ} \mathrm{C}$ and 500 and $600 \mathrm{~mm}$ (hot and humid environment). This indicates that the climate was much wetter than at present $\left(15.6^{\circ}\right.$ $\mathrm{C}$ and $270 \mathrm{~mm}$ ) in the Tébessa region.

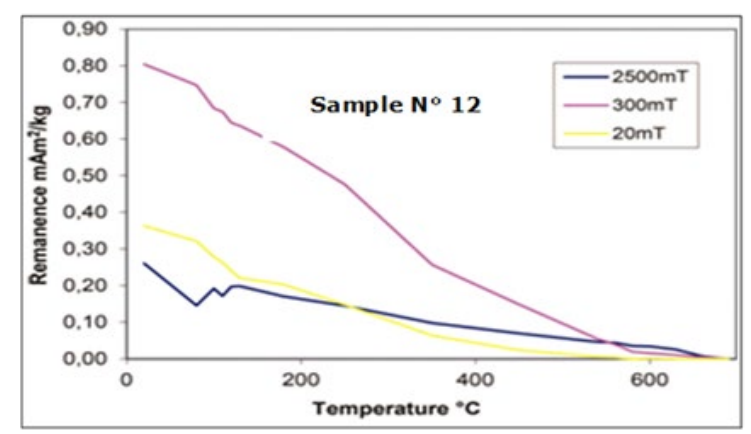

Figure 12: Lowrie diagram of specimen $\mathrm{N}^{\circ} 12$

classification is bad, very bad to very bad and therefore they relate irregularity of the energy level of the transport agent, and more particularly in the level 5 very rich in gravel.

Sediment of level 1,2,3 and 4 show a single stock (uni-modal frequency curves) represented by silts $(>75 \%)$, unlike those of the middle and lower part (levels 2 and 3) are bi to tri-modal, reflecting a mixture of two to three populations (sand and silt). The morphoscopic observation of quartz grains with a dissecting microscope allowed proposing more or less significant changes, since they are often dull or sub-blunted. The abundance of these 
quartz grains families induces a water transport (the importance of fluvial reworking). The magnetic survey is not going against these results. The magnetic parameters have high values in the middle and upper portion, and lower in the lower part. The decrease in the SM values in this part of the terrace is linked mainly to the dominance of gravel and sand (diamagnetic material) deposited under a strong hydrodynamic regime. The dependence of frequency values of magnetic susceptibility ( $\square \mathrm{fd}$ ) are strong throughout the stratigraphic section (except in the lower part) and indicate the presence of a grain size mixture MD, PMD and SP (with a predominance of SP grains). The high percentage of SP grains is linked to the bio-geochemical postdepositional sediment changes (important soil formation). The sedimentary deposit of this cut is implemented during the late Middle Pleistocene (NS-4), the Late Pleistocene (NS-7) and the end of the Pleistocene and the Holocene (NS-1) under conditions milder climate than the present. Variations on the curves of the overall size are the result of the alternation of a calm environment conducive soil formation, with a dynamic system characterized by the dominance of the coarse fraction (gravel and stone).

\section{REFERENCES}

[1] Mastersizer, Initiation au développement de méthode pour les poudres et les suspensions. (2000).

[2] P.L. Folk, W.C. Ward, Brazos river bar: a study in the significance of grain size parameters. Journal of Sedimentary Petrology, 27, (1957) pp. 3-26.France.

[3] A. Rivière, Méthodes granulométriques. Techniques et interprétations. Coll. Techniques et méthodes granulométriques. Masson édition, Paris, (1977). $170 \mathrm{p}$.

[4] K. Pye, S.J. Blott, Particle size analysis of sediments, soils and related particulate materials for forensic purposes using laser granulometry. Forensic Science International. (2004) 144, pp. 19-27.

[5] J.R. Anderson, Sand Sieve Analysis. In Pamela J. W. Gore "Historical Geology Online Laboratory Manual". Department of Geology. Georgia Perimeter College. (2007)278 p.

[6] J.C. Miskovsky. Géologie de la Préhistoire, méthodes, techniques, applications. Association pour l'étude de l'environnement géologique de la Préhistoire. Paris, Géopré, Presses universitaires de Perpignan. (2002),1519 p.

[7] A. Cailleux, J.Tricart, Initiation à l'étude des sables et des galets. Centre de documentation universitaire, Paris, (1963).369 p.

[8] T. Holtzapffel, Les minéraux argileux ; préparation, analyse diffractométrique et détermination. Société géologique du nord, (1985), 12, $136 \mathrm{p}$.

[9] G. Millot, Géologie des argiles. Masson, Paris, (1964). 499 p.

[10] G. Pedro, La classification des minéraux argileux (Phyllosilicates). Étude historique et considérations critiques. Institut National de la Recherche Agronomique. Annales Agronomiques. (1965). 16, 1, 108 p.

[11] M. Rober, Principes de détermination qualitative des minéraux argileux à l'aide de rayons X. Annales Agronomiques. (1975). 26, 4, pp. 363-399.

[12] S.Caillère, M. Henin, Rautureau, Minéralogie des argiles. 1. Structures et propriétés physico-chimiques. INRA, Actualités scientifiques et agronomiques, 8, Masson édition, 2e éd., Paris, (1982) .184 p.

[13] P. Larqué, Diffractométrie. Minéralogie de la fraction argileuse. In : Géologie de la Préhistoire, GEOPRE éditeur, (2002). pp. 601-613.

[14] A. Djerrab, T. Aïfa, Stratigraphy and Palaeoenvironment of the Karaïn Cave Infill, Antalya, Turkey. Rock Magnetic Investigations. Studia Geophysica et Geodaetica, (2010a), 54, pp. 49-76.

[15] A. Djerrab, I. Hedley IEtude des minéraux magnétiques du site préhistorique de la Caverna delle Fate (Finale Ligurie, Savona, Italie). Quaternaire, 21, 2, (2010b). pp. 265-280

[16] W. Lowrie, Identification of ferromagnetic minerals in a rock by coercivity and unblocking temperature properties. Geophys. Res. Lett.17, 2, (1990). pp. 159-162.

[17] W. Westphal et al., Magnetostratigraphy of the lower Triassic volcanics from deep drill SG6 in western Siberia: evidence for long-lasting Permo-Triassic volcanic activity. Geophys. J. Int. 134, (1998). pp. 254-266.

[18] H. Paquet, Evolution géochimique des minéraux argileux dans l'altération et les sols des climats méditerranéens et tropicaux à saisons contrastées. Thèse de Doctorat d'Etat, Université de Strasbourg, (1969). 348 p.

[19] H.Chamley, North Atlantic clay sedimentation and paleoenvironment since the late Jurassic. En: Deep Drilling Research Atlantic Ocean: Continental Margins and paléoenvironment (Talwani, M., Hay, W. and Ryan, W.B.F (Eds.). American Geophysical Union. Maurice Ewing Ser, 3, (1971).pp. 342-361 



\title{
THE GEOCHEMICAL DIVERSITY OF LACUSTRINE SEDIMENTS OF THE SUCHEDNIÓW WATER RESERVOIR (ŚWIĘTOKRZYSKIE VOIVODESHIP, POLAND) - PRELIMINARY RESULTS
}

\author{
DOI: https://doi.org/10.18509/AGB217-40159k
}

UDC: $550.42 .08: 551.312 .4 .051(438)$

Tomasz Kalicki $^{1}$, Rafał Kozłowski ${ }^{2}$, Paweł Przepióra ${ }^{1}$, Mirosław Szwed ${ }^{2}$

\begin{abstract}
${ }^{I}$ Department of Geomorphology and Geoarchaeology, Institute of Geography and Environmental Sciences, Jan Kochanowski University in Kielce, Poland

${ }^{2}$ Department of Environmental Research and Geoinformation, Institute of Geography and Environmental Sciences, Jan Kochanowski University in Kielce, Poland Poland
\end{abstract}

corresponding author:

submitted: 17.01 .2021

accepted: 09.03.2021

published: 20.07 .2021

\begin{abstract}
The research area is located in central Poland, in the Świętokrzyskie Voivodeship (Kielce-Sandomierz Upland). Once heavily industrialized as the former Old Polish Industrial District area, there were many forges and iron furnances developed here. For this purpose, on many rivers of this area the industrial ponds were built. They functioned mainly until the collapse of the metallurgical industry and the water mills as well. Built in 1974 on the Kamionka River in Suchedniów, the water reservoir was use for retention and recreational purposes. Since its construction, the reservoir has never been thoroughly dredged. In 2017, large-scale hydrotechnical works on the reservoir began, aimed at its deepening. Draining the Suchedniów water reservoir made it possible to carry out detailed sedimentological and morphological analyzes of its bottom. A large differentiation of the sedimentary environment types in the reservoir basin has been recognized. The collected samples also provided material for geochemical analyzes. The analysis was made for the content of such trace elements as $\mathrm{Pb}, \mathrm{Cd}, \mathrm{Cr}$, $\mathrm{Co}, \mathrm{Cu}, \mathrm{Mn}, \mathrm{Ni}, \mathrm{Zn}, \mathrm{Sr}, \mathrm{As}, \mathrm{Al}$ and $\mathrm{Fe}$. The known industrial history of this area and the use of the modern reservoir, allows to attempt explain the content changes in the lacustrine sediments
\end{abstract}

Keywords: sedimentology, Suchedniów water reservoir, lacustrine sediments, geochemical diversity, Old Polish Industrail District

\section{INTRODUCTION}

The Holy Cross Mountains area is known from the Prehistorical metallurgical activity during the Roman period [1], [2], as well in the modern period [3]. In the Middle Ages, many forges and water mills were built on the Holy Cross Mountains rivers, on which many smaller ponds were built as the part of hydrotechnical structure. The area was developed because of the rich iron ore deposits, which were mined from the nearby hills [4]. The ore was processed in blast furnances and forges that operated in the Old Polish Industrial District area. In Kamionka, as on many other rivers of this region, they were created anthropogenic small-scale water retention system (ASWRS)[5]. The fall of metallurgy at the beginning of the 20th c. led to the disappearance of ASWRS. In the place of some of the old ponds were built bigger reservoirs, just like at Suchedniów [6]. The Suchedniów water reservoir was built in 1974 in the middle section of Kamionka
River in N of Świętokrzyskie Voivodeship, Poland [7](Fig. 1). During the hydrotechnical works in 2017 the reservoir was drained, giving the opportunity to study of morphology and sediments accumulated for over 40 years in its bottom. The study of heavy metals content in alluvia may indicate long-term changes in river pollution caused by variable anthropogenic influence. Moreover, heavily contaminated sediments may be a potential source of secondary pollution in the future. This problem is marked in the case of water reservoirs that gradually silting. In non-industrialized areas, the composition of sediments accumulating on the reservoir bottom, including the content of heavy metals, depends primarily on the lithology of a given catchment and the climatic conditions that determine the weathering processes and the elements release. The enrichment of heavy metals in water sediments observed in industrialized areas 
is primarily the result of human activities: sewage discharge, emission of pollutants into the atmosphere, which, along with precipitation and surface runoff from areas under the pressure of these emissions, get into surface waters [8], [9], [10], [11].

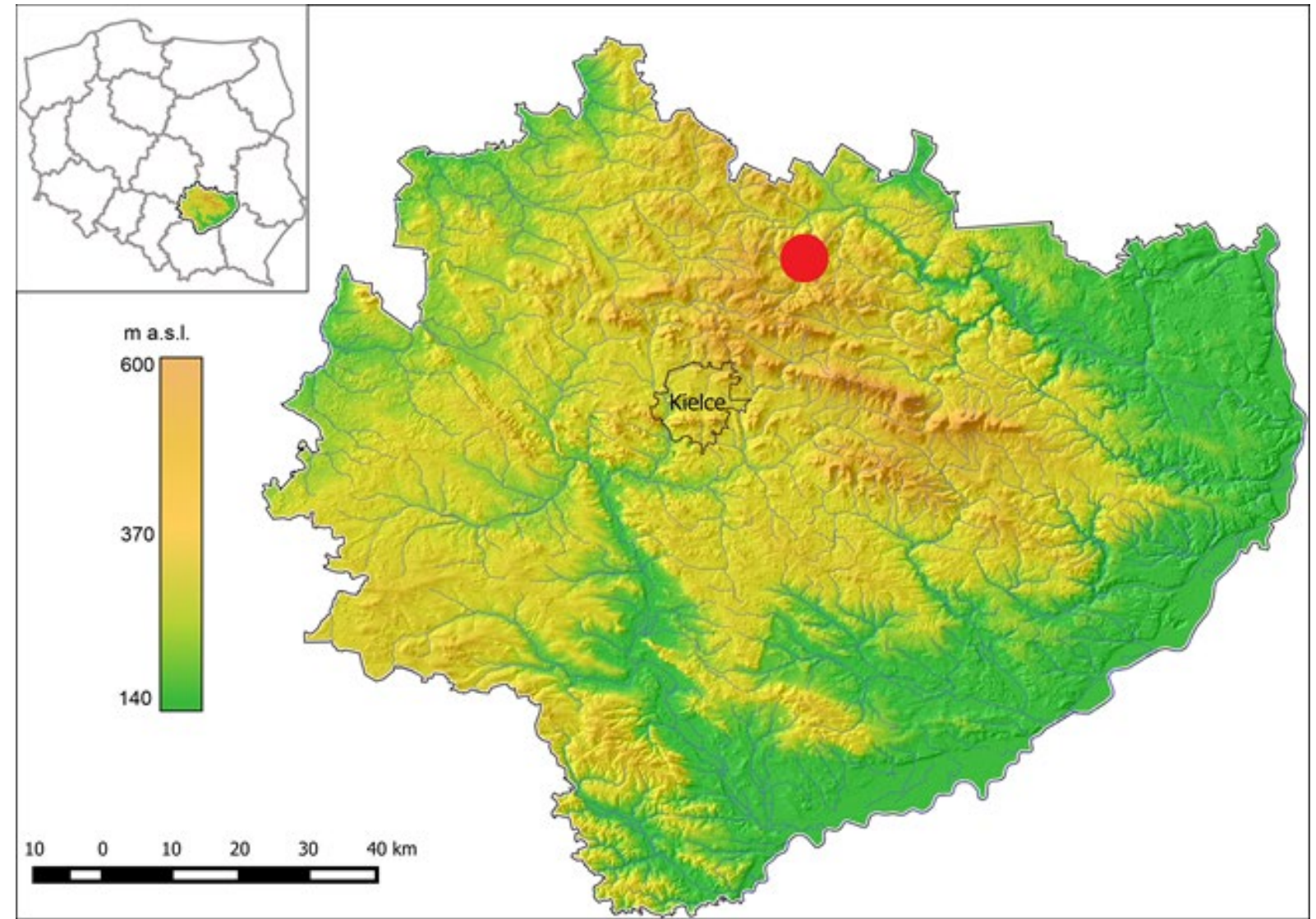

Figure 1. Location of the study area on Digital Elevation Model (DEM)

(By M. Frączek based on date from CODGiK: MGGP Aero, Nr GI-FOTO.703.44.2014)

\section{AIM OF THE STUDY AND METHODS}

The aim of the research was to obtain data about the forms and sediments accumulated in the Suchedniów water reservoir and to capture the diversity of geochemical and sedimentary environments in its basin.

Field work was based on opencast profiles and drillings (using a hand drill and COBRA impact drill). The obtained material was analyzed in grain size terms using sieve and laser method (Mastersizer 3000), pH and geochemical measurement. Basic $\mathrm{pH}$ analyzes of the sediments and the content of trace elements (heavy metals) such as $\mathrm{Pb}, \mathrm{Cd}, \mathrm{Cr}, \mathrm{Co}, \mathrm{Cu}, \mathrm{Mn}, \mathrm{Ni}, \mathrm{Zn}, \mathrm{Sr}, \mathrm{As}, \mathrm{Al}$ and $\mathrm{Fe}$ were performed. Samples collected in the field were analyzed at the "Geomorphological and Hydrological Laboratory” and „Environmental Research Laboratory" of the Jan Kochanowski University in Kielce. In order to determine the chemical composition of heavy metals, the samples were mineralized in the Multiwave 3000 Aanton Paar mineraliser. For this purpose, a sample containing $0.1 \mathrm{~g}$ was weighed and mineralized with nitric acid V (Suprapur Merck 65\%) and perhydrol $(30 \%)$ in a volume ratio of 2.5:1 (microwave power: $1400 \mathrm{~W}$, temperature: $2000 \mathrm{oC}$, time: $40 \mathrm{~min}$ ). After mineralization, the samples were analyzed using the ICP-MS-TOF OptiMass 9500 mass spectrometer (GBC Scientific Equipment, Melbourne, Australia). In order to control the quality of obtained results, certified reference materials such as ERM-CA713 were used.

Based on this data prepared sedimentary, $\mathrm{pH}$ and geochemical map using information obtain from 45 profiles and geological drillings made in the entire reservoir area (samples from the $20 \mathrm{~cm}$ depth were used). These materials have been developed using QGIS and Corel Draw program. 


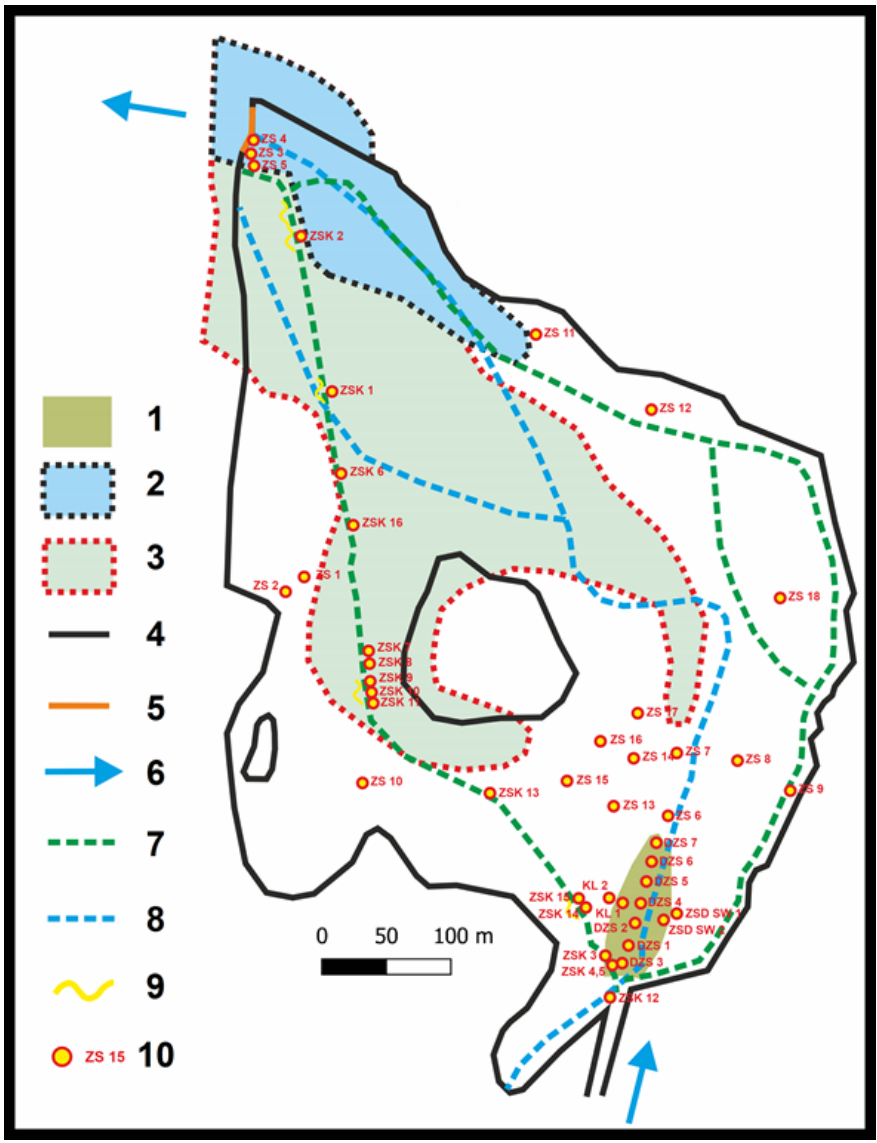

Figure 2. Map of Suchedniów water reservoir:

1 - delta, 2 - water reservoir in 1907-1914, 3 - water reservoir in 1855-1907,

4 - border of modern water reservoir, 5 - dam, 6 - river flow, 7 - drainage channels in 2017,

8 - riverbed before 1974, 9 - mega ripplemarks, 10 - profiles and drillings

In accordance with the adopted geochemical method, the following indicator was employed: geoaccumulation index (Igeo), to assess the pollution of the bottom sediments with heavy metals. The (Igeo) makes it possible to evaluate pollution by comparing current amounts of heavy metals in bottom sediments with the so-called preindustrial concentrations [12], [13]:

Igeo $=\log 2 \mathrm{Cn} / 1,5 \cdot \mathrm{Bn}$

For each metal, the Igeo is classified as:

\section{RESULTS}

The Suchedniów water reservoir was built on the former forge industrial pond area (Fig. 2) and part of the former Kamionka floodplain. After the current reservoir was built, it operated for about 40 years before it was completely drained during hydrotechnical works in order to deepening it. Draining the reservoir revealed the forms and sediments in the bottom [14], [15], [16], [17], as well as many Anodonta anatina shells (Fig. 3), which are an excellent marker of the water cleanliness (bioindicator). During the field work, 45 profiles and boreholes were made (Fig. 2). The samples was collected from the bottom of the reservoir to a depth of $20 \mathrm{~cm}$ for sedimentological
- Igeo class „,0" unpolluted (Igeo $\leq 0$ ),

- Igeo class „1" unpolluted to moderately polluted $(0<$ Igeo $\leq 1)$,

- Igeo class „2" moderately polluted $(1<$ Igeo $\leq 2)$, - Igeo class , ,3" moderately to highly polluted $(2<$ Igeo $\leq 3$ );

- Igeo class ,4” highly polluted $(3<$ Igeo $\leq 4)$,

- Igeo class „,5" highly to very highly polluted ( $4<$ Igeo $\leq 5$ ),

- Igeo class „6” very highly polluted (Igeo $\geq 5$ ).

and geochemical analysis. The Suchedniów water reservoir is a typical flow-through lake used to small retention [19], tourist and recreational purposes. The distribution of sediments on its bottom is quite diverse. There is usually an accumulation of finer sediments in the Kamionka estuary into the reservoir. The sands and sandygravel with an admixture of silty sediments concentrate in the central and northern part of the reservoir. In the western and north-western part the sediments have the most acidic $\mathrm{pH}$, while a small fragment of the bottom near the dam is neutral $\mathrm{pH}$. The average concentrations of trace metals in the analyzed bottom sediment samples are presented in 
the following decreasing sequence $\mathrm{Al}>\mathrm{Fe}>\mathrm{Mn}>\mathrm{Zn}>\mathrm{Sr}>\mathrm{Pb}>\mathrm{Ni}>\mathrm{Cr}>\mathrm{Cu}>\quad \mathrm{Co}>\mathrm{As}>\mathrm{Cd}$. The highest values were recorded for $\mathrm{Al}$ (138328.5 mg.kg-1 dry mass) and Fe (22705.4 mg.kg-1 dry mass), the values of the variation coefficient were the highest for $\mathrm{Cd}$ (120.16) and $\mathrm{Cu}$ (62.42).

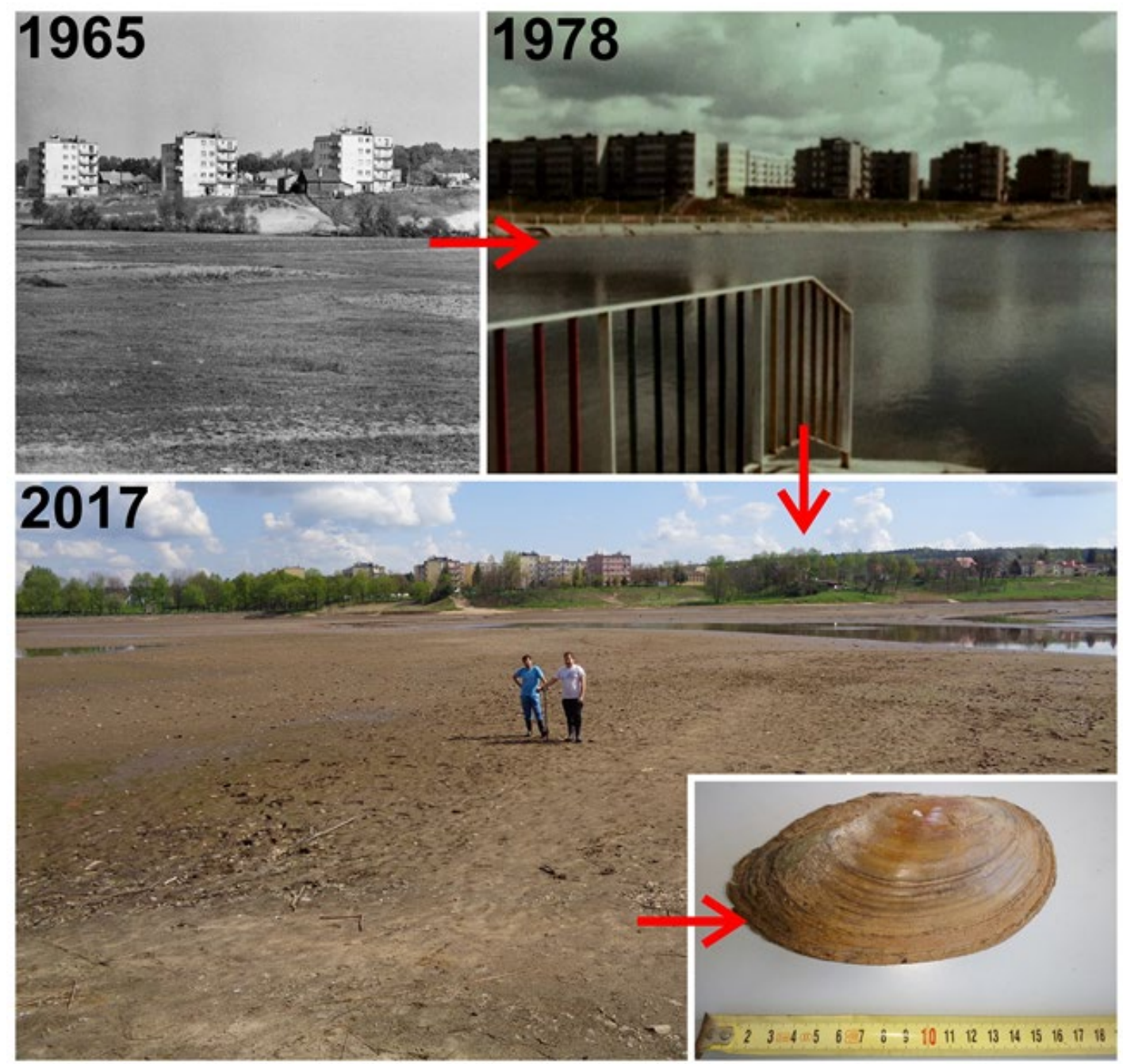

Figure 3. The former flood plain area visible in 1965 and the same area after building the Suchedniów water reservoir in 1978 [18]. Dry reservoir area after hydrotechnical works in 2017 with visible many Anodonta anatina in the bottom (photo by P. Przepióra 2017)

Calculated Igeo [12] in relation to the geochemical background for Poland [21] allowed to classify the analyzed samples into particular classes (Tab. 1). It was shown that the mean values of the Igeo for $\mathrm{Zn}$ and $\mathrm{Cd}$ qualified the analyzed samples as moderately heavily contaminated. In turn, the concentrations of $\mathrm{Co}, \mathrm{Cu}, \mathrm{Mn}, \mathrm{Ni}$ and $\mathrm{As}$ are classified as slightly and moderately polluted. The lowest value of geoaccumulation was calculated for the average concentrations of $\mathrm{Pb}, \mathrm{Cr}$ and $\mathrm{Sr}$ which allows to classify them as practically unpollute.

\section{DISCUSSION}

The many Anodonta anatina shells that were leaved at the bottom of the drained Suchedniów water reservoir. As the excellent bioindicator these mollusks evidenced the relatively high water quality. However, the performed sedimentological and geochemical analyzes showed a very large
Similar classes were divided for the maximum values of the Igeo. The highest values were recorded for $\mathrm{Cd}$ and $\mathrm{Zn}$, and therefore these samples were classified to the 5th class (highly contaminated to very heavily contaminated). The research carried out within the reservoir showed spatial differentiation (Fig. 5). The highest contents of the analyzed metals were found in the southwestern and northern part of the reservoir, where the dam is located.

differentiation of the sediment types at the bottom of the reservoir. Some of them were related to catastrophic events [20] but another with secular processes and long-term human activity. This is also confirmed by geochemical analysis of the sediments, which in the case of selected trace 
elements showed a high level of contamination. The level of contamination is uneven throughout the entire bottom of the reservoir, which may be related

to the overall water circulation of the flow-through reservoir type. Where the water is still, sediments with pollutants supplied by the river from the upper parts of the catchment area are accumulated, while at the place where the delta was formed (high flow energy) in the Kamionka river estuary, these pollutants were washed away. The research carried out [22] on the Suchedniów water reservoir showed similar values of geoaccumulation indicators, but apart from $\mathrm{Cd}, \mathrm{Zn}$ and $\mathrm{Cu}$, an increased value for $\mathrm{Pb}$ was found (class 1). The highest concentration of pollutants can be noted in the northern and western parts of the reservoir, where the $\mathrm{pH}$ of the sediments is very acidic.

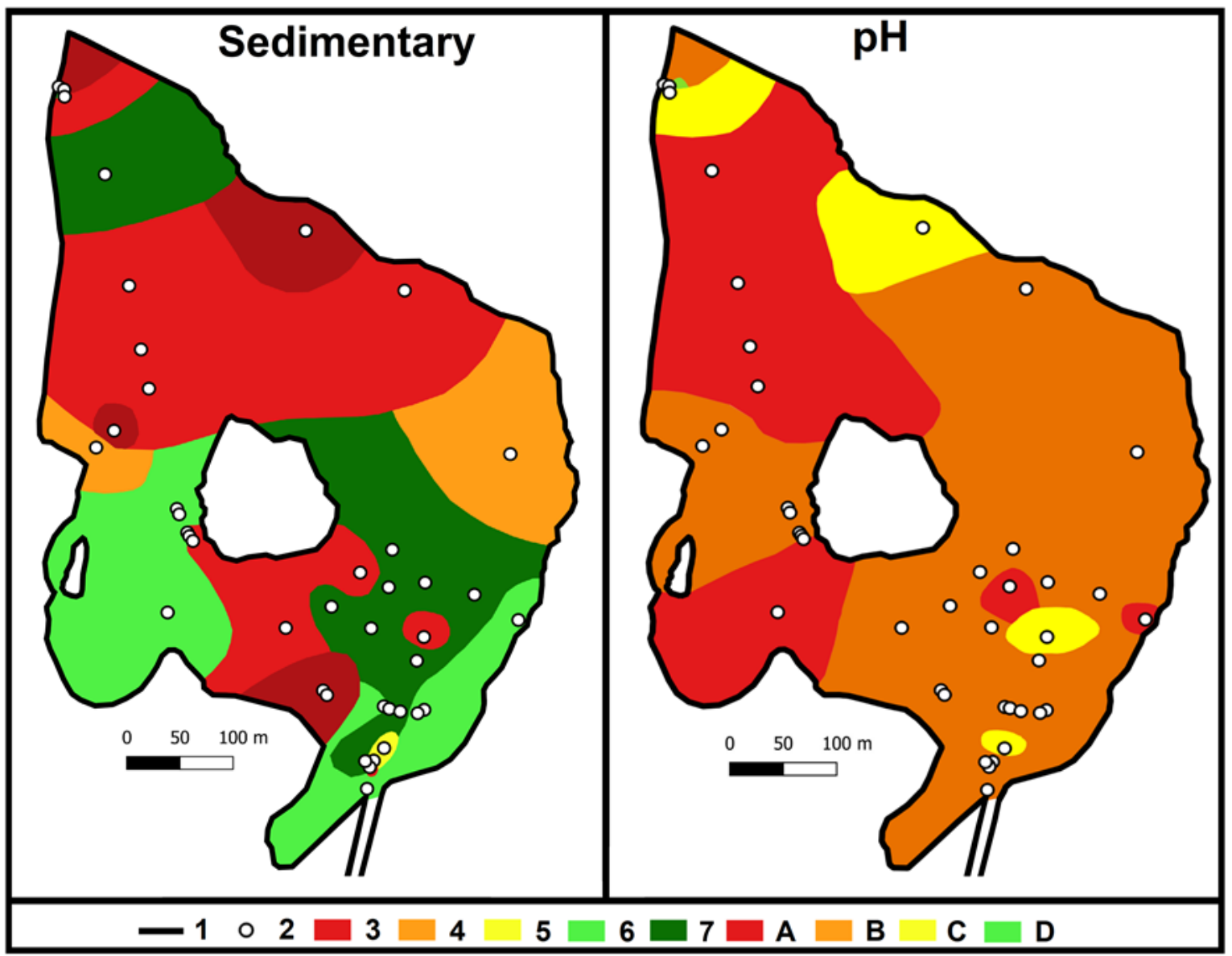

Figure 4. Suchedniów reservoir bottom sedimentary and $\mathrm{pH}$ map to $20 \mathrm{~cm}$ depth; Lithology:

1 - border of modern water reservoir, 2 - profiles and drillings, 3 - sand with single gravels, 4 - medium sand, 5 - fine sand, 6 - sandy silt, 7 - silt and clay; pH: A - strong acidic, B - acidic, C - lightly acidic, D - neutral [20]

Table 4. The content of selected heavy metals and the

values of the Igeo in the analyzed sediment samples

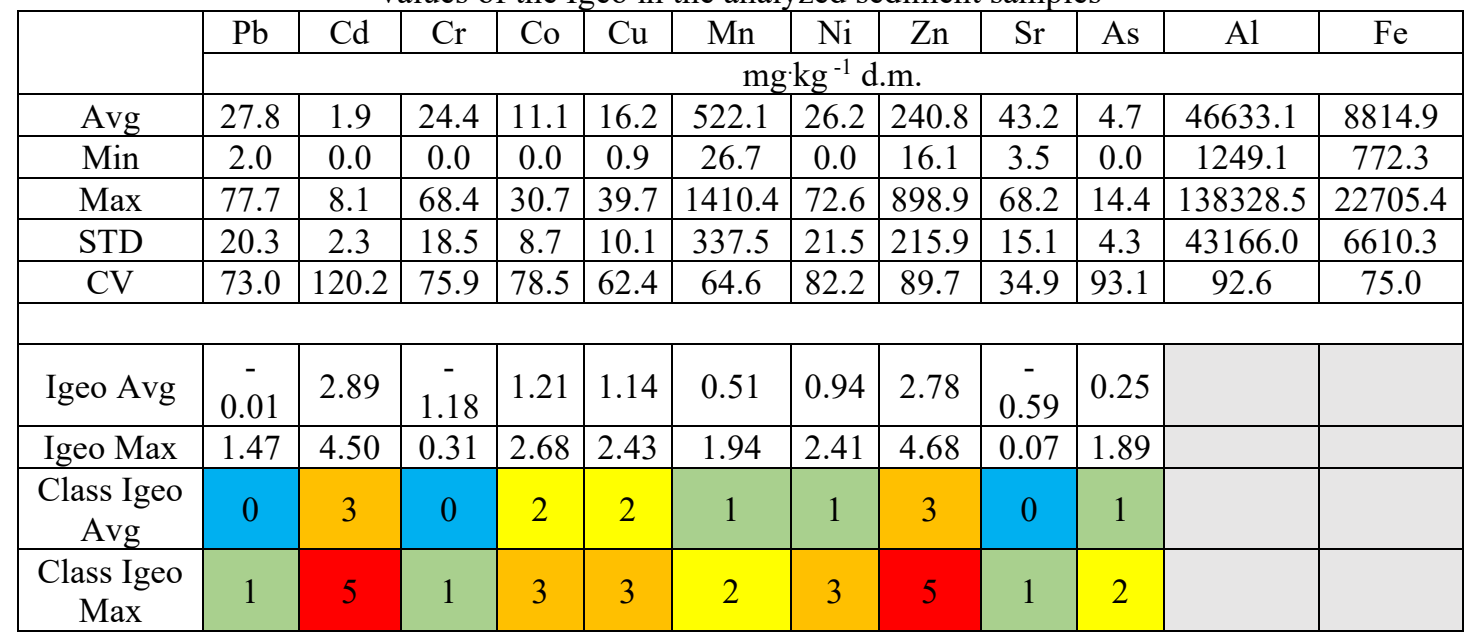




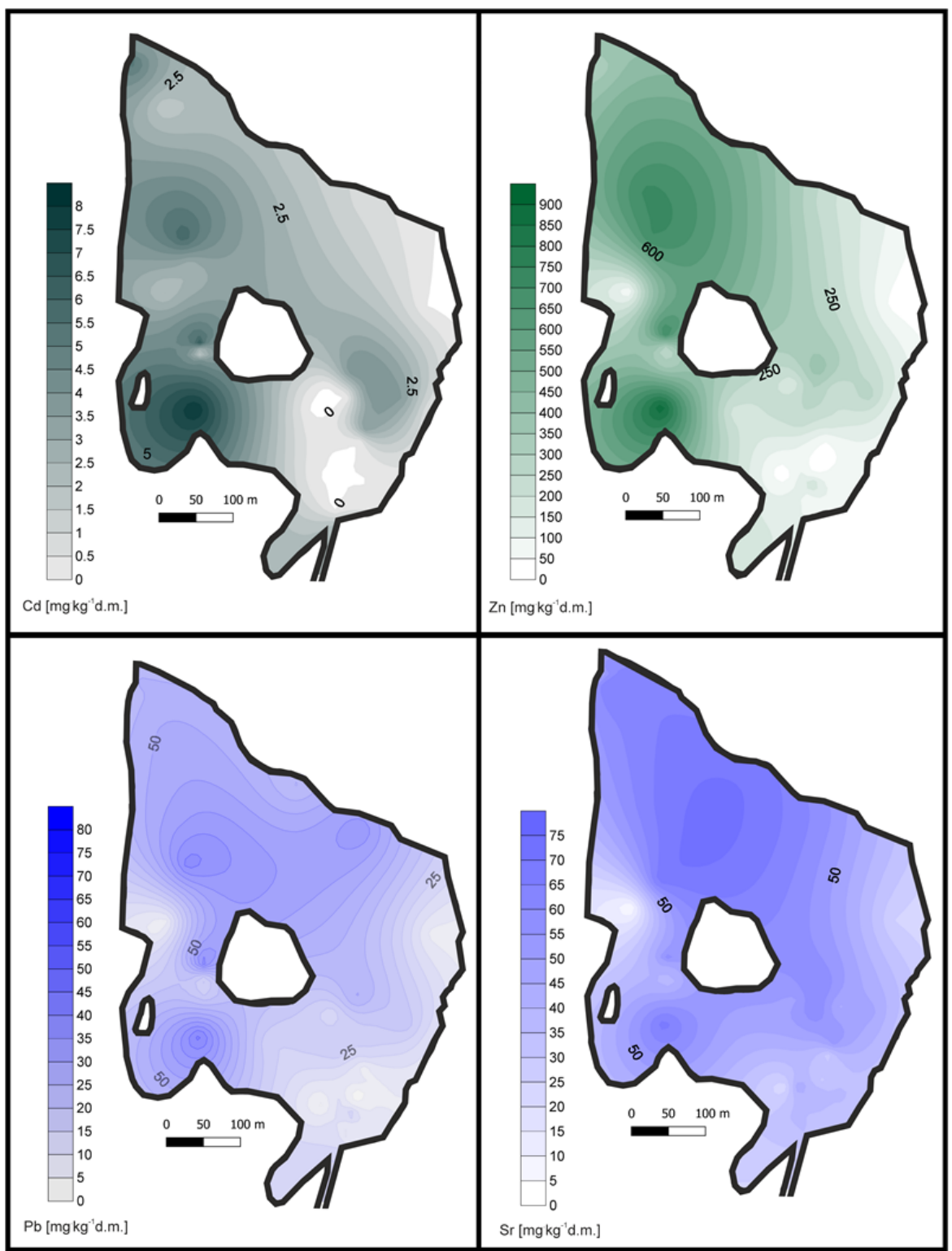

Figure 5. Spatial content of selected heavy metals

$(\mathrm{Cd}, \mathrm{Zn}, \mathrm{Pb}, \mathrm{Sr})$ in the Suchedniów water reservoir bottom

\section{CONCLUSIONS}

Before its dredging (until 2017), the Suchedniów water reservoir was characterized by a high rate of heavy metal contamination in its northern and western parts. It is related to the land use in the catchment and the reservoir development. The nature of the flow-through reservoir type also leads to the washout of contaminants from one part of it and the accumulation of trace elements in another. The concentration of pollutants can also be associated with the sediment type accumulated in the reservoir bottom as a result of various rapid (catastrophic) and long-term (secular) events [20].

\section{REFERENCES}

[1] Bielenin K. Starożytne górnictwo i hutnictwo żelaza w Górach Świętokrzyskich, Wydanie drugie, poszerzone i poprawione, Kieleckie Towarzystwo Naukowe, 1992.

[2] Orzechowski Sz. Zaplecze osadnicze i podstawy surowcowe starożytnego hutnictwa świętokrzyskiego, Kieleckie Towarzystwo Naukowe, Kielce, 2007.

[3] Przepióra P. Naturalne i historyczne zmiany zlewni Kamionki (Płaskowyż Suchedniowski), PhD thesis, Jan Kochanowski University in Kielce, 2017.

[4] Przepióra P., Kalicki T., Nowak E., Kusztal K., Houbrechts G., Pabian G., Peeters A., 2021. Historical mining remains preserved in the present-day relief of the European Hercynian Mountains - Casestudies from Holy Cross 
Mountains (Poland) and Ardennes (Belgium). Acta Geobalcanica, 7-3, pp 109-115.

[5] Kalicki T., Przepióra P., Kusztal P., Chrabąszcz M., Fularczyk K., Kłusakiewicz E., Frączek M. Historical and present-day human impact on fluvial systems in the Old-Polish Industrial District (Poland). Geomorphology, available online 12 February 2020. https://doi.org/10.1016/j.geomorph.2020.107062, 2020.

[6] Kalicki T., Frączek M., Przepióra P., Kusztal P., Kłusakiewicz E. \& Malęga E. Late Quaternary geomorphology and geoarchaeology in the rivers of the Holy Cross Mountains region, central Europe, Quaternary Research, Special Issue, pp 1-16, 2018.

[7] Piasta S. Leksykon Suchedniowa, Towarzystwo Przyjaciół Suchedniowa, Kielce, 2012.

[8] Bojakowska I., Sokołowska G. Geochemiczne klasy czystości osadów wodnych. Przegląd Geologiczny, 46 (1), pp 49-54, 1998.

[9] Loska K., Wiechula D., Korus I. Metal contamination of farming soils affected by industry. Environment International 30, pp. 159-165, 2004.

[10] Chen, C. W., Kao, C. M., Chen, C. F. \& Dong, C. D. Distribution and accumulation of metals in sediments of Kaoshiung Harbor,Taiwan, Chemosphere 66, pp 1431-1440, 2007.

[11] Kostecki J., Greinert A., Wasylewicz R., Adam R., Garbera B., Knap P., Ostapkowicz M., Stanisławiak B. Spatial distribution of heavy metals in the topsoil on roundabouts in Zielona Góra, Poland. Environmental Protection and Natural Resources 26 no 2(64), pp 1-8, 2015.

[12] Müller G. Index of Geoaccumulation in Sediments of the Rhine River. Geo. Journal, 2, pp 109-118, 1969.

[13] Müller G. Die Schwermetallbelastung der Sedimenten des Neckars und Seiner Nebenflu“sse. Chemiker-Zeitung 6, pp 157-64, 1981.

[14] Biesaga P., Kalicki T., Frączek M. \& Przepióra P. Gilberts delta in Suchedniów reservoir, 24. Kvarter, Brno, pp 14, 2018.

[15] Kalicki T., Przepióra P., Aksamit M., Biesaga P., Frączek M., Kłusakiewicz E., Grzeszczyk P., Chrabąszcz M. \& Kusztal P. Formy i osady Zalewu Suchedniowskiego (województwo świętokrzyskie) - wstępne wyniki, [in:] Cłapa T., Dawidowicz L. \& Szymański E.M. (ed.) Nauka dla środowiska, vol 3, Uniwersytet Przyrodniczy w Poznaniu, University of Technology in Poznań, pp 70-76, 2018.

[16] Kalicki T., Przepióra P., Aksamit M., Biesaga P., Frączek M., Kłusakiewicz E., Grzeszczyk P., Chrabąszcz M. \& Kusztal P. Zróżnicowanie osadów wypełniających Zalew Suchedniowski (województwo świętokrzyskie), [in:] Kostrzewski A., Stach A. \& Majewski M. (ed.) Geneza, Litologia i Stratygrafia Utworów Czwartorzędowych, vol. VII, Instytut Geoekologii i Geoinformacji UAM, Poznań, pp 69-73, 2018.

[17] Przepióra P., Kalicki T., Aksamit M., Biesaga P., Frączek M., Grzeszczyk P., Malęga E., Chrabąszcz M., Kłusakiewicz E., Kusztal P., Secular and catastrophic processes reflected in sediments of the Suchedniów water reservoir, Holy Cross Mountains (Poland). Geologos 25 (2) pp 139-152, 2019.

[18] www. facebook.comSuchedniowWczoraj

[19] Bąk Ł., Górski J. \& Szeląg B. Wpływ kaskady zbiorników małej retencji Suchedniów i Rejów na redukcję fali wezbraniowej na rzece Kamionka, Acta Sci. Pol., Formatio Circumiectus, vol. 11, no. 1, pp 13-22, 2012.

[20] Przepióra P., Kalicki T., Aksamit M., Biesaga P., Frączek M., Grzeszczyk P., Malęga E., Chrabąszcz M., Kłusakiewicz E., Kusztal P., Secular and catastrophic processes reflected in sediments of the Suchedniów water reservoir, Holy Cross Mountains (Poland). Geologos 25 (2), pp 139-152, 2019.

[21] Salminen R., (Chef Editor) Batista M. J., Bidovec M., Demetriades A., De Vivo B., De Vos W., Duris M., Gilucis A., Gregorauskiene V., Halamic J., Heitzmann P., Lima A., Jordan G., Klaver G., Klein P., Lis J., Locutura J., Marsina K., Mazreku A., O’Connor P.J., Olsson S.Å., OttesenR.T., Petersell V., Plant J.A., Reeder S., Salpeteur I., Sandström H., Siewers U., Steenfelt A. and Tarvainen T. FOREGS Geochemical Atlas of Europe, Part 1: Background Information, Methodology and Maps. Geological Survey of Finland, Espoo, pp 526, 2005.

[22] Sałata, A., Bąk, Ł., Chmielowski, K., Rabajczyk, A. Metal pollution of sediments in small water reservoirs in the Kielce Highland (South Eastern Poland). Archives of Environmental Protection 45 (2), pp 12-21, 2019 



\title{
EFFICIENCY OF HALOTHERAPY IN IMPROVING HUMAN PERFORMANCE IN GYMNASIUM STUDENTS)
}

DOI: https://doi.org/10.18509/AGB217-40167a

UDC: $615.834-057.875$

\author{
Mihaela-Orlanda Antonovici (Munteanu) ${ }^{1}$, Ion Sandu ${ }^{2,3}$, \\ Ioan Gabriel Sandu ${ }^{4,5}$, Cristina Carmen Stingu (Palici) ${ }^{6}$, \\ Simona Dimitriu (Ursache) ${ }^{1}$
}

\author{
${ }^{\prime}$ Alexandru Ioan Cuza University, Faculty of Geography and Geologie, Geoscience Doctoral School, Environmental \\ Science Field, Iasi, România \\ ${ }^{2}$ Alexandru Ioan Cuza University, ARHEOINVEST Interdisciplinary Platform, Iasi, Romania \\ ${ }^{3}$ Romanian Inventors Forum, Iaşi, Romania \\ ${ }^{4}$ Alexandru Ioan Cuza University of Iasi, Interdisciplinary Research Department - Field Science, Iaşi, Romania \\ ${ }^{5}$ Gheorghe Asachi Technical University of Iasi, Faculty of Material Sciences and Engineering Iaşi, Romania \\ ${ }^{6}$ Vasile Alecsandri University of Bacau, Department of Environmental Engineering and \\ Mechanical Engineering, Bacau, Romania
}

corresponding author:

\begin{abstract}
The paper presents on the basis of studies conducted in recent years in our team on the generation, chemical, physical and structural characterization and dynamics of saline aerosols, their role in increasing the anatomical structural performance for students. Halotherapy is performed by inhaling saline aerosols through the airways, as well as by absorbing them on the skin. The salt nanoparticles have a considerable negative charge $\left(6-10 \mathrm{nK} / \mathrm{m}^{3}\right)$, and the surface of the airway has a slight positive charge, with a wide range of dimensions, from the Aitken type (between the single ion, as such or solvate, and nanostructural aggregates smaller than $50 \mu$ to the sedimentable aggregate (with a diameter greater than $500 \mu$ to $1000 \mu$ ) [1].Regarding these nanoparticles, a series of artificial halochambers were developed, which were experimented in teaching activities with students, in Physical Education classes and for other study disciplines. Thus, a series of diaphragm generators containing porous $\mathrm{NaCl}$ granules were used, obtained by recrystallization from supersaturated solutions and which were arranged in the classrooms (two in number), as well as in the gym, which operated. as halochambers. Students were monitored twice a week for the evolution of morphostructural and biometric characteristics. For each work program, the level of saline aerosols / solions was correlated with the average data of the biometric characteristics of the students, separated by sex. For Aitken particles, the lifespan varies between 12 and 72 hours. Thus, it was proved by the obtained results that these nanoparticles have a beneficial influence on the development of high school students, females having higher receptivity to the effect of improving human performance.
\end{abstract}

Keywords anhydrous saline aerosols, solions, Aitken particles, halochamber, halotherapy.

\section{INTRODUCTION}

The paper aims to study the impact of saline aerosols on morpho-structural and functional characteristics of students, as well as on the evolution of their health, focusing on the harmonious development of human subjects studied, students of grades VI and VII, with ages 12-15. Therapy with natural or artificial saline aerosols is considered a procedure for the prevention and treatment of respiratory diseases, as it contributes to increasing resistance to weathering, aggression of gases and dusts in the air, thus reducing long-term drug treatment and improving school activity while reducing the number of missed classes through medical exemption. The salt particles contribute to the increase of the organism's resistance against respiratory infections and have desensitizing effects to allergens, having a considerable negative charge $(6-10 \mathrm{nK} / \mathrm{m} 3)$, and the surface of the airways has a slight positive electric charge, therefore, the salt have the ability to enter the respiratory system and "bind" to the airway epithelium.Working with high school 
students, such on-site research would benefit both the health of the students and the school in improving school performance and maintaining a healthy climate. The movement in the halochamber increases the resistance to stress, improves the power of concentration, offers emotional stability and a general state of comfort. Saline aerosols also have positive effects on the skin system. According to literature, they normalize skin microbiocenosis, increase skin elasticity and have a bacteriostatic, anti-edematous and anti-inflammatory effect. The therapeutic potential of natural or artificial saline aerosols is in the attention of researchers around the world to obtain new scientific, argumentative data

\section{THE EXPERIMENTAL PART}

\section{Methods and techniques used in determining the characteristics of saline aerosols}

Both methods for determining the climatic parameters of an enclosure and a series of specific methods were used to measure and monitor the composition of the atmosphere in the halocamera, such as: SIBATA GT 321 particle counter and Dust Trok, a ionometer type Air Ion Counter and climatic factors in the classrooms involved were monitored as follows:

temperature $\left({ }^{\circ} \mathrm{C}\right)$, air humidity $\left(\begin{array}{ll}\% & \mathrm{RH}\end{array}\right)$, atmospheric pressure (mmHg) and lighting (lx), using specific laboratory devices.

\section{Work Methodology}

The study used semi-dry aeration generating devices, consisting of a fan and a diaphragm containing porous granules extruded from recrystallized rock salt from supersaturated solutions. \% RH and $20 \ldots 22^{\circ} \mathrm{C}$ ). In the classrooms where the study was conducted, four generators were placed at the level of the windows, with a volume of $126 \mathrm{~m} 3$ of air $(7 \times 6 \times 3)$ and six in the gym of $320 \mathrm{~m} 3(10 \times 8 \times 4)$. To achieve an optimal level in

\section{Selecting the groups of students for the trials}

The trials were performed on students in grades VI and VII, from which there were selected for each age category, noted by year of birth (2006 and 2007), two groups of students (girls and boys): the reference group for applications outdoors or gym, composed of the group of girls marked F0i200X (X $=6$ and 7), consisting of students $i$, with the year of birth 200X and the group of boys marked B0i200X, composed of the student $i$, with the year of birth 200X and respectively the batch group consisting of the group of girls marked Fhi200X with students i, with the year of birth 200X and the group of boys marked Bhi200X with the student $i$, with the year of birth $200 \mathrm{X}$, where $\mathrm{i}=1,2,3 \ldots$, represents the to support these holistic therapies [1]. Related to these nanoparticles, a series of patented artificial halochambers were developed, which were experimented in teaching activities with students. With their help, it has been shown that active solions at a certain level of concentration have a beneficial influence on the development of young people, the female sex having a higher receptivity regarding the effect of improving human performance [2],[3]. In this sense, the influence of the active time of standing in the halochamber is studied, which is ten times longer than in other studies of the team [4],[5]..

solutions, the generators were turned on about 60 minutes before the start of class. After 50 minutes of operation, the average level of solion was determined, and then determined again at the end of the hours. For the Physical Education classes followed a progressive program of exercises, trainings and games for a period of 50 minutes, twice a week, distributed at intervals approximately close in time. The fans allow the circulation of 28 $32 \mathrm{~m} 3 / \mathrm{h}$, so $112-128 \mathrm{~m} 3 / \mathrm{h}$, respectively, 168$192 \mathrm{~m} 3 / \mathrm{h}$. Saline aerosol generators, by erosion, take up nanoparticles of salts from the labile crystallites of the efflorescences on the surface of the granules and disperse them into the halochamber atmosphere, where under the influence of air humidity they are structurally reformulated as oligomers of salt and pentahydrol nanocrystallites. spherical glomeruli with negative aeroion behavior. The glomeruli have a superficial monomolecular layer of water dipoles with a negative charge on the outside.

number of the student in the group, each group with 7 to 25 students.

In order to select students for the two experimental groups (halochamber and outdoor) a series of data were used according to a standard form that includes information on family living conditions, heredocolateral history (hemophilia, diabetes, hypertension, parasitosis). , heart disease, cancer, rheumatic diseases, TB), personal physiological, pathological history (eruptive diseases, whooping cough, hepatitis, gastritis, cardiovascular, immunological, metabolic and endocrine disorders). Following the examination of the subjects and the analysis of the completed forms, 
the following were established: living conditions, type of family, global attitude of the body and others .Students were closely monitored during the school year so that twice a week (Tuesday and Friday), at the beginning and end of the week, in terms of morphostructural and biometric characteristics. For each work program, the level of saline aerosols / solutions was correlated with the average data of the biometric characteristics of the students, separated by sex [6].

Table 1. The climatic characteristics of the two systems used in the experiment (open air and halochamber).

\begin{tabular}{|c|c|c|c|c|c|c|}
\hline The system & The parameter & Oct 2017 & Oct 2018 & Feb.2019 & Oct.2020 & Feb.2021 \\
\hline \multirow{4}{*}{$\begin{array}{c}\text { Open air or } \\
\text { gym } \\
\text { (witness) }\end{array}$} & $\mathrm{T}^{\circ} \mathrm{C}$ & 20 & 20 & 20 & 21 & 20 \\
\hline & P,atm & 750 & 740 & 740 & 750 & 750 \\
\hline & UR, \% & 70 & 60 & 65 & 60 & 60 \\
\hline & $\mathrm{I}, \mathrm{lx}$ & 120 & 116 & 112 & 118 & 120 \\
\hline \multirow{5}{*}{$\begin{array}{c}\text { Halochamber } \\
\text { I and II }\end{array}$} & $\mathrm{C}, \mathrm{mg} / \mathrm{m}^{3}$, saline aerosols & 0,649 & 0,667 & 0,682 & 0,669 & 0,705 \\
\hline & $\mathrm{T}^{\circ} \mathrm{C}$ & 20 & 20 & 20 & 21 & 20 \\
\hline & P,atm & 750 & 740 & 740 & 750 & 750 \\
\hline & UR, \% & 65 & 65 & 65 & 60 & 65 \\
\hline & $\mathrm{I}, \mathrm{lx}$ & 85 & 80 & 80 & 82 & 85 \\
\hline $\begin{array}{c}\text { Classroom } \\
\text { I and II } \\
\text { witness }\end{array}$ & $\begin{array}{l}\mathrm{C}, \mathrm{mg} / \mathrm{m}^{3}, \text { saline aerosols } \\
\mathrm{T} \circ \mathrm{C}, \\
\mathrm{P}, \mathrm{atm} \\
\text { UR, \% } \\
\mathrm{I}, \mathrm{lx}\end{array}$ & $\begin{array}{l}0 \\
21 \\
750 \\
75 \\
110\end{array}$ & $\begin{array}{l}0 \\
22 \\
740 \\
70 \\
105\end{array}$ & $\begin{array}{l}0 \\
22 \\
760 \\
75 \\
110\end{array}$ & $\begin{array}{l}0 \\
22 \\
760 \\
75 \\
120\end{array}$ & $\begin{array}{l}0 \\
21 \\
750 \\
70 \\
110\end{array}$ \\
\hline
\end{tabular}

\section{Determining the Biometric Characteristics}

During the morpho-structural and functional biometric examination, in order to determine the level of physical development of the subjects, a series of measurements were performed, namely:

- the weight, which was performed with the help of the electronic scale and was expressed in kilograms;

- stature (height), which was determined with the staturometer, being expressed in centimeters;

- the thoracic perimeter, respectively the thickness of the thorax, was measured with a metric band $(100 \mathrm{~cm})$, registering two dimensions, with the thoracic perimeter at respiratory rest (moment between inspiration and expiration) and respectively the thoracic perimeter in maximum inspiration, this study was presented in a previous communication [7]. In the present paper only the following characteristics are studied:

- lung capacity, determined by means of the portable spirometer Peak Flow Meter PFM20, Peak A-I-R, Omron, the maximum volume of exhaled air expressed in $\mathrm{L} / \mathrm{min}$, and

- pulse or heart rate, determined by the device digital sphygmomanometer HZ-8501.

\section{Processing trial data}

Since we worked with a heterogeneous group of students with many characteristics dependent on exogenous factors (environmental), but also on endogenous ones (genetic dowry), in order to facilitate the interpretation of experimental results we resorted to the graphical representation of the growth percentage in time. In order to do this, the biometric data were determined periodically, at 12 ,
24 , and 40 months, respectively, to establish the evolution of the maximum expired air volume for the students studied. Based on the recorded data, a primary table was prepared. Then the average of the values for the same period evaluated for each group of students was calculated, respectively the group of girls, denoted F0m200X and the group of boys, denoted B0m200X, where $\mathrm{m}$ represents the arithmetic mean, and $X$ - the values 6, 7, corresponding to the year of birth. After this, the percentage $(\%)$ was calculated by how much the characteristic $\mathrm{C}$ evolved, compared to the start time of the experiment $\left(\mathrm{C}_{0}\right)$, in relation to the subsequent readings $(\mathrm{Cj})$, the determination period being denoted by $j$, which represents the month of the year of readings, using the relationship:

$$
\begin{gathered}
\mathrm{C}(\%) \mathrm{F}_{0 \mathrm{~m}} 200 \mathrm{X} \text { or } \mathrm{C}(\%) \mathrm{B}_{0 \mathrm{~m}} 200 \mathrm{X}=100 \times(\mathrm{Cj}- \\
\mathrm{C} 0) / \mathrm{C}_{0}, \\
\text { respectively, } \\
\mathrm{C}(\%) \mathrm{F}_{\mathrm{hm}} 200 \mathrm{X} \text { or } \mathrm{C}(\%) \mathrm{B}_{\mathrm{hm}} 200 \mathrm{X}=100 \times(\mathrm{Cj}- \\
\left.\mathrm{C}_{0}\right) / \mathrm{C}_{0} ;
\end{gathered}
$$

Finally, the graphs $\mathrm{C}(\%)=\mathrm{f}(\mathrm{t})$ are drawn, the time being in months, for the average values of girls and boys, in the two different working conditions, taken separately (outdoors, noted in the lower right index " 0 " and halochamber, denoted in the lower right index "h"). Each biometric characteristic studied was represented in the same coordinate system, having in ordinate $\mathrm{C}(\%)$ and in abscissa time in months. Based on these graphs, the evolution of each group of students was assessed and the influence of saline aerosols and reformulations in situ on the characteristics studied was established. 


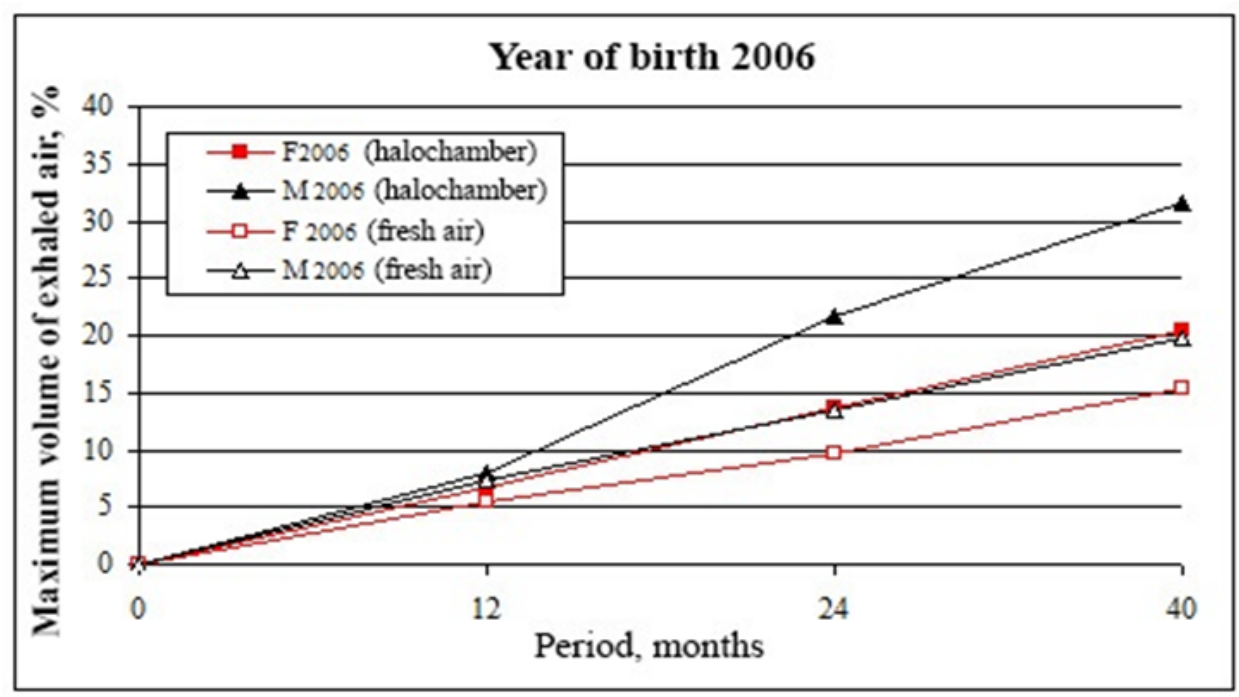

Figure 1. The evolution of the maximum expired air volume for the students born in 2006 taken in the study.

The primary data were recording in a tabular system, followed by their processing and graphical representation of the evolution over time of morphostructural characteristics (weight, height, thoracic perimeter), which was studied and presented in a previous article for each group of students on the two age levels $(2006,2007)$ and gender [7].

Regarding the evolution of the maximum volume of exhaled air, in the case of students born in 2006 there was a higher increase in the case of boys (Fig. 1), the difference between the percentage increases recorded by the group in the halochamber and the control group being $11.91 \%$ for boys and only $5.21 \%$ for girls. It should be noted that in the first 12 months the percentage increases for girls and boys are very close, and only after this interval the group of boys who worked in the halochamber registered a more accentuated increase.

For the groups of students born in 2007, the evolution of the maximum volume of exhaled air (Fig. 2) shows a clear difference between the percentage increase of the volume of exhaled air in girls compared to boys, the value of this percentage reaching up to $24.48 \%$ in the case of girls, compared to only $18.30 \%$ among boys.

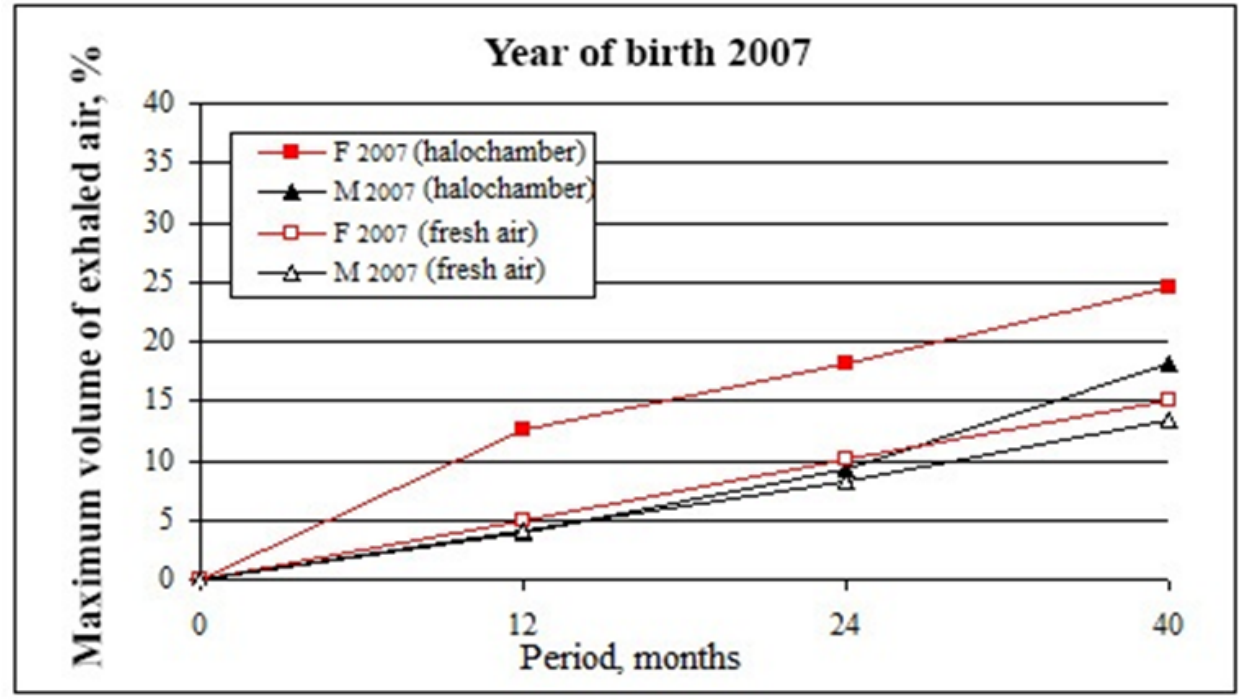

Figure 2 The evolution of the maximum expired air volume for the students born in 2007 taken in the study

The groups that operated outdoors only slightly exceeded the threshold of $15.00 \%$ (15.09\% boys, $13.33 \%$ girls), the percentage of growth registering close values throughout the monitoring. In the first 24 months, the percentage values recorded in the evolution of the group of boys who carried out activities in the halochamber were close to those of the control groups and then distanced quickly, while the percentage evolution of the maximum volume of expired air only currently displaying higher growth rate. Regarding the evolution of heart rate or pulse, in the case of the group born in 2006 
(Fig.3), there is a decrease in the number of beats / minute recorded after exertion, the decrease being more pronounced in the case of boys. At the beginning of the study period, the difference between the average pulse recorded before and after exertion in boys who worked in the halochamber was 39 beats / min, and at the end of the period it reached 25 beats / min. A more pronounced reduction in the difference between the values recorded at rest and those after exercise is observed after the first 24 months. The common peak recorded at measurements taken after 24 months can be attributed to health problems.

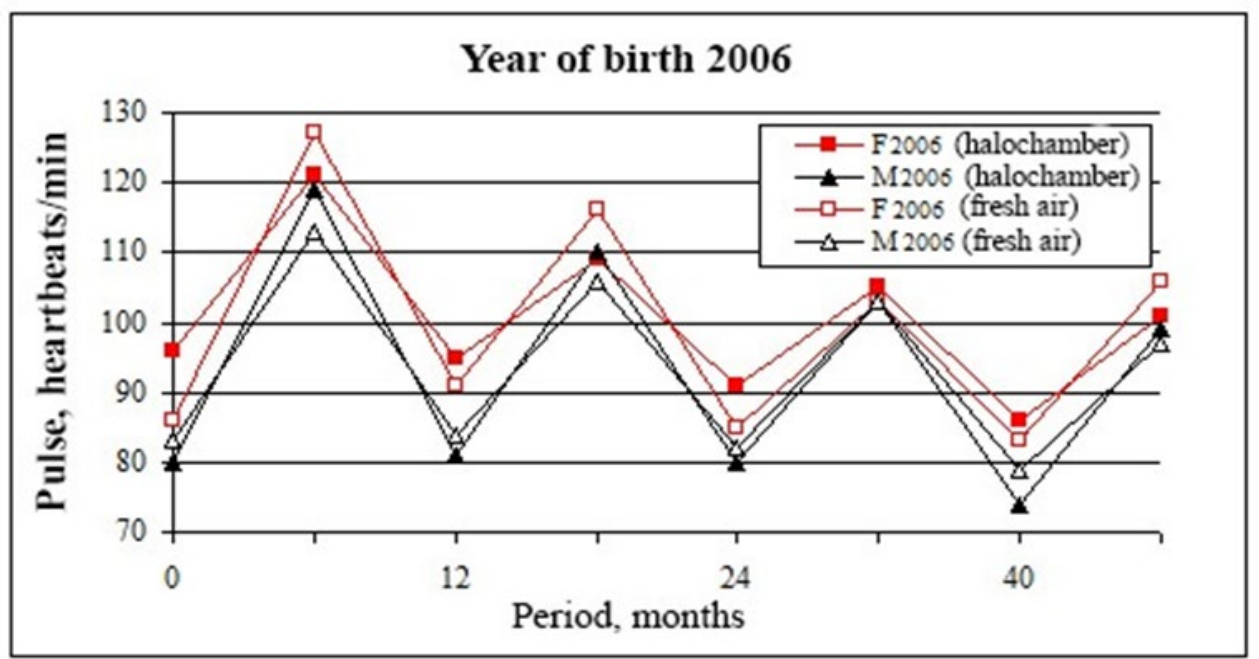

Figure 3. Evolution of the pulse for students born in 2006 studied

For the groups born in 2007 the pulse registered in the first 12 months (Fig. 4), indicates approximately the same values after the effort, same the girl group as for the boy group. Then, after the first 12 months, there is a decrease in the number of beats / minute, after the effort the decrease is more pronounced in girls $(\mathrm{Fhm} 2007=123-103$ beats $/ \mathrm{min}, \mathrm{F} 0 \mathrm{~m} 2007=$ 126-109 beats $/ \mathrm{min})$, than in boys $(\mathrm{Mhm} 2007=$
115-97 beats $/ \min , \mathrm{M} 0 \mathrm{~m} 2007=117-100$ beats $/$ $\min$ ).

The results obtained after relaxation in boys vary very little compared to girls. The boys who worked in the halocamera had lower values, while the girls in the halocameras had higher values than those in the open air. In both sexes, there was a reversal between the two work regimes..

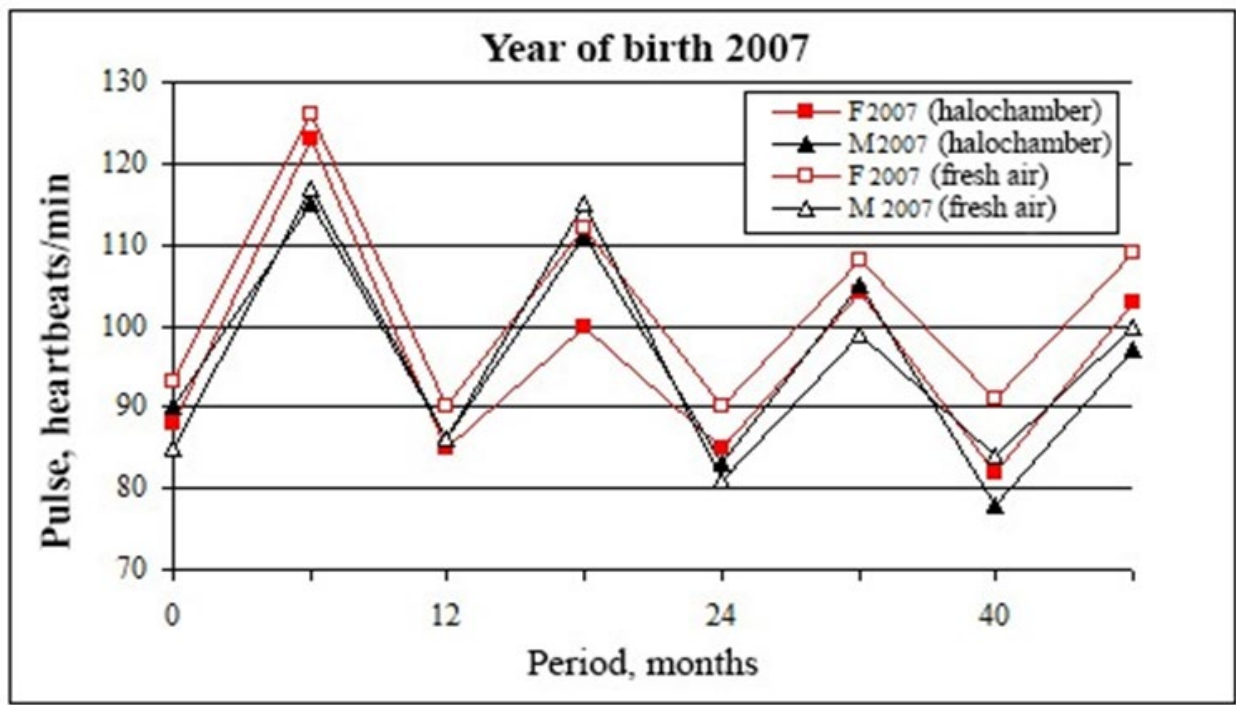

Figure 4. Evolution of the pulse for students born in 2007 studied.

\section{RESULTS AND CONCLUSIONS}

Based on the experimental data obtained on some groups of students, one witness, who worked on the sports field or in the gym and other who performed in the classrooms, differentiated on sex and by age, including children born in 2006 and 2007, the following conclusions can be drawn:

- saline aerosols and solions reformulated in situ act on the body by inhalation and absorption in 
the skin, which according to the literature offers a remedy for many diseases, halotherapy being a complementary and / or alternative method of airway protection and improvement of the morpho-structural characteristics of the human organism;

- the correct and systemic practice of movement games in an environment with solutions contributes substantially to the development of students' resistance to diseases, to a better functioning of the body and to obtaining sports performances;

- Class and physical education classes in schools in an environment with saline aerosols / solions can help the proper functioning of the body, they have a positive impact on school activities and sports competitions of students, implicitly on human performance;

- the experimental data processing system regarding the evolution of the characteristics studied, expressed by percentage increase, allowed a good highlighting of the effect of saline aerosols / solions on the biometric characteristics of morpho-structural type (weight, height, thoracic perimeter) in children, these have been studied and exposed in a previous article according to age and sex [7].

- the evolution graphs of weight and height show a higher percentage increase in the case of girls; the percentage difference between the increase registered in the group in the halochamber and that in the control group being higher in girls than in boys, although the route of the two curves for girls is sometimes below the evolution curves of growth for boys, are data that have been studied and previously presented [7].

-before performing the spirometry, a procedure performed in the school medical office, the data of human subjects (height, weight, age) were recorded, their evolution either in the halocamera, experimental group or in the room without saline aerosol generator, control group, being presented previous.

-the studies were performed for groups of students, control and experimental, on the evolution of growth in height, weight, expressed in a previous article, [7], these measurements being performed before performing spirometry, through the maximum volume of air inhaled, exhaled, then interpretation respiratory system indices, gave us a starting point and a subsequent positive evolution of respiratory parameters, both for the experimental group and for the control group, highlighting a more pronounced increase for the experimental group.

-the existing microclimate in saline, has a major contribution on the human body, numerous studies conducted so far, have registered favorable results only in the prevention and treatment of non-chronic respiratory diseases, without paying attention to the impact on intellectual and physical performance of students , grouped by age, sex, control and experimental group. The research of our team targeted high school students, on whom saline aerosols had a special influence.

- saline aerosols and solions reformulated in situ act on the body by inhalation and absorption in the skin, which according to the literature offers a remedy for many diseases, halotherapy being a complementary and / or alternative method of airway protection and improvement of the morpho-structural characteristics of the human organism [8].

- the correct and systemic practice of movement games in an environment with saline aeroanions / solions contributes substantially to the development of students' resistance to diseases, to a better functioning of the body and to obtaining sports performances [9].

- classes held in schools in an environment with saline aerosols / solions can help the proper functioning of the body, they have a positive impact on school activities and sports competitions of students, implicitly on human performance [10].

- the experimental data processing system regarding the evolution of the characteristics studied, expressed by percentage increase, allowed a good highlighting of the effect of saline aerosols / solions on some functional biometric characteristics in children, depending on age and sex;

- the difference between the percentage increases registered by the batch group and the control group born in 2006 is $11.91 \%$ for boys and only $5.21 \%$ for girls, noting that in the first 12 months the percentage increases, recorded both among the girls, as well as among the boys, they are very close, so that then the group of boys, who worked in the halochamber, will register a more accentuated growth;

- for the groups of students born in 2007 there is a clear difference between the percentage increase of the volume of exhaled air in girls compared to boys, the value of this percentage reaching up to $24.48 \%$ in the case of girls, compared to only $18.30 \%$ among boys, the lots that worked outdoors not exceeding, only very little the threshold of $15.00 \%$, throughout the monitoring registering quite close values;

- regarding the evolution of the heart rate / pulse, in the case of the group born in 2006, there is a decrease in the number of beats / minute recorded 
after exertion, which is more pronounced in boys, at the beginning of the study period, the difference between the average pulse recorded before and after exertion in the boys who worked in the halochamber it was 39 beats / min, and at the end of the period it reaches 25 beats / min, a more accentuated reduction of the difference between the values recorded at rest and those after exertion being observed after the first 24 months, where the common PIK can be attributed to health problems, which have occurred for some members of the group;

- for the groups born in 2007, the pulse registered after exertion in the first 12 months, indicates close values, both for girls and boys, after which a decrease of the number of beats/minutes is observed, the decrease being more accentuated in the case of girls, than in boys;].

\section{ACKNOWLEDGMENTS}

This work was supported by a grant of the Romanian Ministery of Research and Innovation, CCCDI UEFISCDI, project number PN-III-P1-1.2 - PCCDI-2017-0239/60PCCDI 2018, within PNCDI III.

\section{REFERENCES}

[1] Sandu I, Canache M, Sandu IG, Pascu C, Sandu AV, et., al. Researches on the NaCl Saline Aerosols III. Influence of Physical Doping with other Sals on Aerosols Generations: Aerosol and Air Quality Research, 10(6): 1731-1740, (2013)

[2] Sandu I, Canache M, Chirazi M, Sandu AV, Matei PN. et al. Artificial Halochamber for Multiple Users and Reactivation Process. Patent RO128973 (B1)/2013-11-29, 2013.

[3] Sandu I, Canache M, Lupascu T, Chirazi M, Sandu AV, et al. Artificial halochamber (embodiments), process for loading and process for reactivation of used salt granules (embodiments), Patent MD4239 (B1)/2013.07.31, 2013.

[4] Sandu I, Canache M, Mihaescu T, Chirazi M, Sandu AV, et al. Influence of $\mathrm{NaCl}$ Aerosols on the Functional Characteristics of Children., Revista de Chimie (Bucharest), Romania, 66(1): 60-65, 2015.

[5] Sandu I, Canache M, Sandu AV, Chirazi M, Mihaescu T, et al. The influence of $\mathrm{NaCl}$ aerosols on weight and height development of children, Envi Moni Asse, 187(2): 15, 2015.

[6] Sandu I., Canache M., Sandu A.V., Vasilache V. Aerosolii salini în dezvoltarea copiilor. Editura Universităţii "Alexandru Ioan Cuza" Iaşi, Romania, pp.195, 2015.

[7] Antonovici M.O., Chim. Sandu I., Chim. Vasilache V., Sandu A.V., Sandu I.G., Stangu C.C., The impact of saline aerosols on students physical performance, Acta Geobalcanica, Macedonia, vol.6/issue 2, pp.65-73,2020.

[8] Kanny G., Surdu O., Boulange M. Halothérapie et spéléothérapie : se soigner dans les mines de sel. Hegel, vol.9, Nr. 1, 2019.

[9] Ştirbu C.M., Ştirbu I.C., Sandu I., Impact Assessment of Saline Aerosols on Exercise Capacity of Athletes. Procedia - Soci and Behavi Sci , 46: 4141-4145, 2012.

[10] Pascu, C., Sandu, I., Ciobanu, G., Sandu, I.G., Vasile, V., Ciobanu, O.,Sandu, A.V., Pascu A., Method and Device for Determining Saline Aerosols "in situ".Patent RO122232/27.03.2009. 

